\title{
Proveniência e paleocorrentes de conglomerados e arenitos do Grupo Santa Bárbara (Ediacarano) no Vale do Piquiri, Sub-bacia Camaquã Oriental, RS: implicações tectônicas
}

\author{
Provenance and paleocurrents of conglomerates and sandstones of \\ the Santa Barbara Group (Ediacaran) in the Piquiri Valley, Eastern \\ Camaquã Sub-basin, Rio Grande do Sul, Brazil: tectonic implications
}

\author{
Gelson Luís Fambrini ${ }^{1}$, Renato Paes de Almeida ${ }^{2}$, Liliane Janikian ${ }^{3}$, Claudio Riccomini² \\ 'Departamento de Geologia, Centro de Tecnologia e Geociências, Universidade Federal de Pernambuco - UFPE, Avenida \\ Acadêmico Hélio Ramos s/n, sala 510 - Cidade Universitária, CEP 50740-530, Recife, PE, BR (gelson.fambrini@ufpe.br) \\ 2Departamento de Geologia Sedimentar e Ambiental, Instituto de Geociências, Universidade de São Paulo - USP, São Paulo, \\ SP, BR (rpalmeida@usp.br, riccomin@usp.br) \\ 3Universidade Federal de São Paulo - UNIFESP, Diadema, SP, BR (lijanikian@gmail.com, lijanikian@yahoo.com.br)
}

Recebido em 15 de maio de 2016; aceito em 26 de maio de 2017

\begin{abstract}
Resumo
A Sub-bacia Camaquã Oriental compreende exposições da borda leste da Bacia do Camaquã, como o Vale do Piquiri, pertencentes ao Grupo Santa Bárbara (Ediacarano). Estudos estratigráficos de fácies, sistemas deposicionais, proveniência e paleocorrentes conduziram à subdivisão do Grupo Santa Bárbara na Sub-bacia Camaquã Oriental em duas unidades: (i) Formação Passo da Capela, formada por turbiditos de leques subaquosos; e (ii) Formação Rincão dos Mouras, constituída por arenitos e conglomerados de leques aluviais e sistemas fluviais entrelaçados. Este artigo propõe formular um modelo de evolução de altos estruturais durante o preenchimento de uma bacia rifte. Conglomerados de leques subaquosos da Formação Passo da Capela apresentam composição do arcabouço derivada da própria bacia (arenitos), indicando autofagia, além de rochas do embasamento (quartzitos, xistos, metarriolitos). Análises de paleocorrentes indicam dispersão dos sedimentos segundo NNE, compatível com litotipos do Complexo Porongos (quartzitos, metarriolitos, milonitos). A norte, análises de proveniência dos conglomerados indicam derivação principalmente do Sienito Piquiri, e também de outras litologias. Esse fato sugere que a proveniência reflete contribuição do embasamento adjacente (clastos do Sienito Piquiri), com pouco ou nenhum transporte. Conglomerados aluviais da Formação Rincão dos Mouras contam com proveniência diversificada. Na base ocorrem clastos metamórficos do Complexo Porongos (metarriolitos) e da própria bacia (arenitos). Análises de proveniência sugerem denudação do Complexo Porongos (altos de embasamento) e da bacia. A porção intermediária apresenta clastos de granitos róseos/muscovita leucogranitos correlacionáveis ao Batólito Pelotas, e litologias do Complexo Porongos. Sienitos e traquitos aparecem em pequena proporção, assim como arenitos. Análises de proveniência, aliadas às de paleocorrentes, indicam que áreas a leste estavam sendo soerguidas e erodidas, como Batólito Pelotas e Complexo Porongos, comportando-se como altos de embasamento fornecedores de sedimentos para a bacia. No topo predominam fragmentos do Complexo Porongos (mármores). Análises de paleocorrentes realizadas na Formação Rincão dos Mouras sugerem controle tectônico importante durante o preenchimento da unidade, com mudanças de fontes de detritos para a bacia e soerguimento de altos internos. As análises de proveniência levadas a efeito em todas as unidades (i) indicaram sempre fonte adjacente aos depósitos sedimentares; (ii) demonstraram as fontes de detritos; e (iii) auxiliaram na diferenciação entre as formações Passo da Capela e Rincão dos Mouras. A ocorrência na Formação Rincão dos Mouras de fragmentos de mármore e o aumento considerável da proporção de clastos do Granito Encruzilhada do Sul, situado a ENE da região do Vale do Piquiri, foi mais um dos critérios utilizados na separação das unidades, sobretudo quando conglomerados estratificados de ambas se acham contíguos.
\end{abstract}

Palavras-chave: Grupo Santa Bárbara; Bacia do Camaquã; Estratigrafia; Análise de proveniência; Paleocorrentes; Ediacarano. 


\begin{abstract}
The Eastern Camaquã Sub-basin comprises exposures of Eastern border, as the Piquiri Valley, belonging to the Santa Barbara Group (Ediacaran). Stratigraphic studies of facies, depositional systems, provenance and paleocurrentes led to the subdivision of the Santa Barbara Group on Eastern Camaquã Sub-basin in two units: (i) Passo da Capela Formation, formed by turbidites of subaqueous fans; (ii) Rincão dos Mouras Formation, that consists of sandstones and conglomerates of alluvial fans and fluvial braided systems. This article proposes a model of structural highs evolution during the filling of a rift basin. Subaqueous fan conglomerates of Passo da Capela Formation feature framework composition derived the basin (sandstones), indicating autophagy, and rocks of the basement (quartzites, schists, metarhyolites) also occur. Paleocurrent analyses indicate dispersal of sediments toward NNE, compatible with lithotypes of the Porongos Complex (quartzites, metarhyolites, mylonites). Northward, provenance analyses of conglomerates indicate derivation mostly from Syenite Piquiri, but also from other lithologies. This fact suggests a local contribution (clasts of Syenite Piquiri), with little or no transportation. Alluvial conglomerates of the Rincão dos Mouras Formation have diverse provenance. Provenance analysis suggests denudation of the Porongos Complex (basement highs), exemplified by metarhyolites, and of the own basin (sandstones). Middle portion presents clasts of granites/muscovite leucogranites correlated to the Pelotas Batolith, and lithologies of the Porongos Complex. Syenites and trachytes appear in small proportion, as well as sandstones. Provenance and paleocurrent analyses indicate that areas to the east were being uplifted and eroded, such as Pelotas Batolith and Porongos Complex, behaving like basement highs, supplying sediments to the basin. At the top fragments of the Porongos Complex predominate (marbles). Paleocurrent analyses in the Rincão dos Mouras Formation suggest important tectonic control during the filling of the unit, with shifts in sources of debris to the basin and uplift of internal highs. Provenance analysis carried out in all units (i) indicated always adjacent sources to the sedimentary deposits, (ii) demonstrated the sources of debris, and (iii) assisted in the differentiation between Passo da Capela and Rincão dos Mouras formations. The occurrence in this last unit of marble fragments and the considerable increase in the proportion of clasts related to the Encruzilhada do Sul Granite, located ENE of the region of the Piquiri Valley, were two important criteria used to differentiate both units, especially when stratified conglomerates of both are contiguous.
\end{abstract}

Keywords: Santa Bárbara Group; Camaquã Basin; Stratigraphy; Provenance analysis; Paleocurrents; Ediacaran.

\section{INTRODUÇÃO}

Estudos estratigráficos de fácies e sistemas deposicionais (e.g. Fragoso-Cesar, 1984; Lavina et al., 1985; Paim, 1994, 1995; Fambrini, 2003; Fambrini et al., 2005, 2007; Fambrini e Fragoso-Cesar, 2006; Almeida et al., 2009, 2010; Marconato et al., 2014), aliados a análises de paleocorrentes e sistemas deposicionais (e.g. Paim et al., 1992; Paim, 1994; Fambrini et al., 1998; Paim et al., 2002) e análises de proveniência e paleocorrentes (e.g. Fambrini et al., 1992; Fambrini et al., 2014; Sayeg et al., 1992; Caravaca et al., 1995; Caravaca, 1998; Fambrini, 1998; Fambrini et al., 1998, 2006, 2007, 2014; Bicca et al., 2013), têm propiciado contínuos avanços no entendimento da evolução tectono-sedimentar da Bacia do Camaquã e de seu preenchimento, o Supergrupo Camaquã. No entanto, no tocante à Sub-bacia Camaquã Oriental, os estudos realizados são ainda incipientes e carecem de integração com todos os dados disponíveis. Como forma de reparar tal carência, o presente trabalho visou apresentar análises estratigráficas de proveniência e paleocorrentes, aliadas a estudos de fácies, sistemas deposicionais e à integração com modelos de evolução de bacias rifte, com implicações tectônicas e paleogeográficas.

O intervalo situado entre o Ediacarano e o Cambro-Ordoviciano na porção sudeste da Plataforma Sul-Americana registra a presença de ocorrências sedimentares e vulcano-sedimentares geradas após os eventos orogênicos do Ciclo Brasiliano. Essas ocorrências, esparsamente aflorantes do sul de Minas Gerais ao sul do Uruguai (Figura 1), originaram-se em bacias tectônicas alongadas segundo direção variável entre NNE a ENE associadas a falhas de mesma orientação do embasamento sobre o qual se dispõem. Os depósitos dessas bacias são constituídos por espessas sucessões de conglomerados, arenitos e pelitos de ambientes continentais aluviais, deltaicos e lacustrinos (e.g. Paim, 1994; Paim et al., 2002; Fambrini et al., 2014; Marconato et al., 2014), frequentemente associados a rochas vulcanogênicas de afinidade calcialcalina de alto-K a shoshonítico (e.g. Lima e Nardi, 1998; Widner et al., 2002; Janikian et al., 2003; Sommer et al., 2006; Janikian et al., 2012), incluindo alguns intervalos interpretados como marinhos (e.g. Fragoso-Cesar et al., 1984, 1985; Paim et al., 1986; Fambrini, 2003; Fambrini e Fragoso-Cesar, 2006).

De acordo com Almeida (1969), a mais completa e melhor exposta dessas ocorrências é a Bacia do Camaquã, situada na porção centro-sul do estado do Rio Grande do Sul (Figura 1), onde recobre rochas pré-cambrianas do embasamento e compreende espessas sucessões siliciclásticas e vulcanogênicas (Ribeiro et al., 1966), classificadas como molassas do fim da Orogenia Brasiliana (Almeida, 1969; Tessari e Giffoni, 1970; Fragoso-Cesar et al., 1982, 1984; FragosoCesar, 1984, 1991), e posteriormente interpretadas como registros de bacias transcorrentes (Oliveira e Fernandes, 1991; Machado e Sayeg, 1992; Caravaca, 1998) ou vinculadas a retro-arco de antepaís do orógeno desse ciclo no sul do Brasil (Gresse et al., 1996). Em trabalhos posteriores, elementos de campo indicaram que a Bacia do Camaquã é produto de evolução extensional, constituindo um sistema de riftes possivelmente sem vinculação com o Ciclo Brasiliano (Fragoso-Cesar et al., 2000, 2001; Almeida, 2001; 


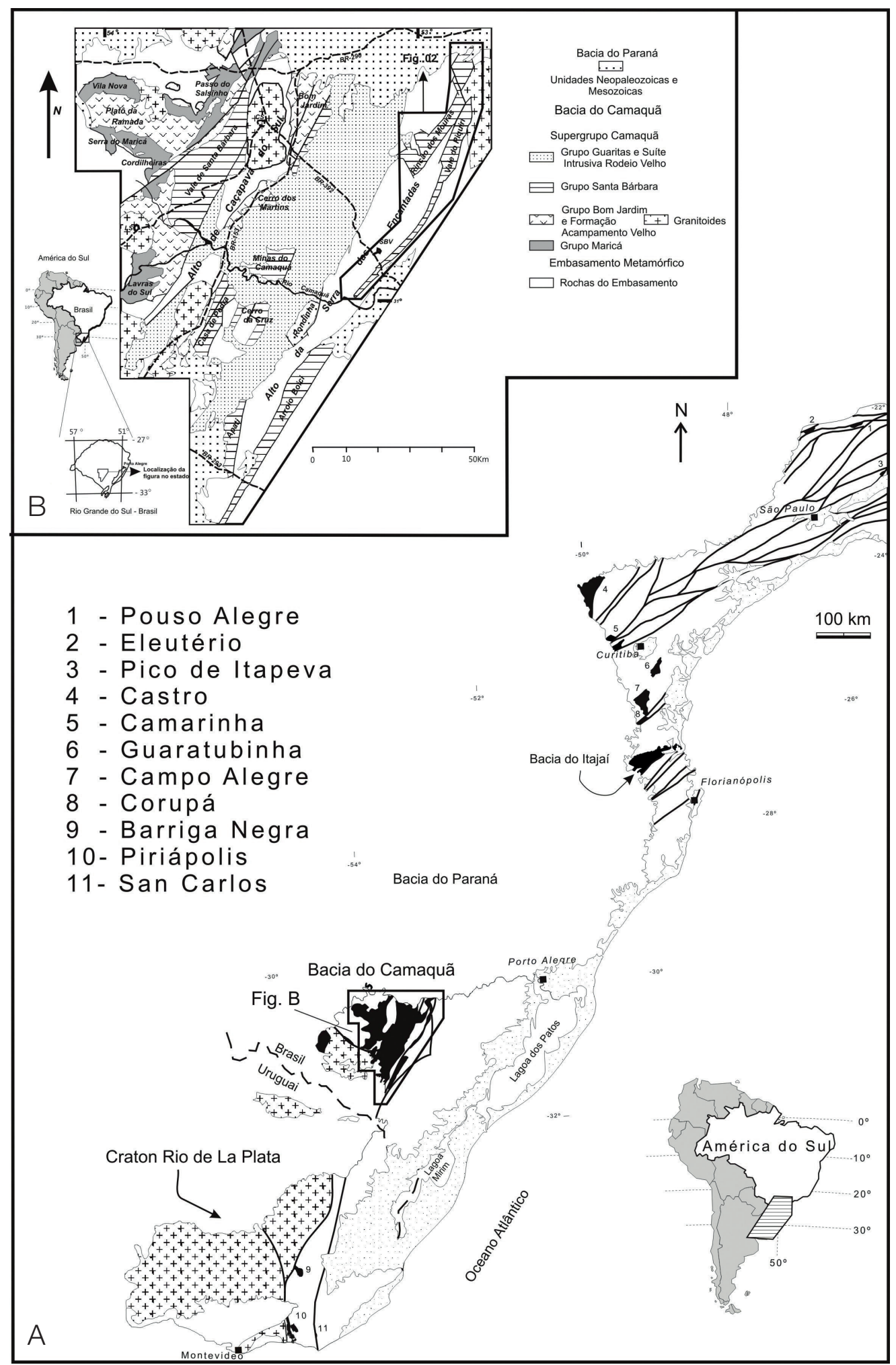

Fonte: modificada de Fragoso-Cesar et al., 2000; Fambrini, 2003.

CS: Caçapava do Sul; LS: Lavras do Sul; SBV: Santana da Boa Vista.

Figura 1. Esboço geológico das unidades neoproterozoicas e paleozoicas do Sudeste da América do Sul. (A) bacias sedimentares do fim do Neoproetrozoico e início do Paleozoico na porção sudeste da Plataforma Sul-Americana; (B) mapa geológico esquemático das unidades neoproterozoicas e eopaleozoicas do Rio Grande do Sul, com destaque para as unidades que constituem o Supergrupo Camaquã. 
Fambrini et al., 2001; Fambrini, 2003; Fambrini e FragosoCesar, 2006; Fambrini et al., 2005, 2006, 2007, 2011, 2014; Almeida et al., 2009, 2010, 2012), também interpretada como um sistema anorogênico (Fragoso-Cesar et al., 2002, 2003; Fragoso-Cesar, 2008).

Sob enfoque litoestratigráfico, como resultado de investigações regionais em todas as sub-bacias, e de detalhe em diversos trechos dessas ocorrências, Fambrini et al. (1996), Fambrini (2003) e Fambrini et al. (2003, 2005, 2006, 2007, 2014) constataram que correlações estratigráficas, estruturais, litológicas e paleoambientais indicam que as unidades Santa Bárbara e Arroio dos Nobres são correlacionáveis, ocupando mesma paleogeografia em contexto tectono-sedimentar similar (Fambrini e Fragoso-Cesar, 2006). Tendo em vista que a designação Santa Bárbara - definida informalmente por Robertson em 1961, manuscrito publicado em 1966 - possui prioridade sobre a designação Arroio dos Nobres, optou-se que essa unidade passe a ser denominada de Grupo Santa Bárbara (Fambrini et al., 2003, 2005).

A Sub-bacia Camaquã Oriental (Figura 2) situa-se na borda leste da Bacia do Camaquã e ocupa uma depressão tectônica alongada segundo a direção preferencial NNE-SSW, preenchida por sucessões siliciclásticas imaturas que, localmente, ultrapassam $6.000 \mathrm{~m}$ de espessura. Limita-se a leste e oeste com as rochas metavulcânicas e metassedimentares do Complexo Porongos na porção intermediária a meridional por contato tectônico, principalmente falhas normais a oblíquas de direção NE e NNE. Essas falhas extensionais, posteriormente reativadas como falhas transcorrentes, colocaram altos do embasamento em meio aos depósitos sedimentares. A sub-bacia limita-se com o Granito Encruzilhada do Sul em sua extremidade setentrional. A norte é recoberta por sedimentos paleozoicos da Bacia do Paraná. Na Sub-bacia Camaquã Oriental, o Supergrupo Camaquã é representado por rochas eminentemente sedimentares do Grupo Santa Bárbara, que se assentam diretamente sobre o embasamento ígneo-metamórfico. O Grupo Santa Bárbara encontra-se basculado por tectônica de blocos associada às falhas normais a oblíquas, sendo comuns mergulhos entre 25 e $80^{\circ}$ para W e, em parte das exposições, para SW. Localmente, no contato com o Sienito Piquiri, no extremo nordeste da sub-bacia, a relação de contato ocorre como não conformidade indicando a proximidade da área fonte e os produtos dela derivados.

O Grupo Santa Bárbara (Ediacarano) apresenta cerca de $6.000 \mathrm{~m}$ de espessura na Sub-bacia Camaquã Oriental (Fambrini, 2003; Fambrini e Fragoso-Cesar, 2006). O grupo é representado por sucessões de arenitos e ritmitos lacustres, e de conglomerados e arenitos aluviais e deltaicos, dispostos em ciclos progradacionais e retrogradacionais, separados por discordância erosiva (Fambrini, 2003; Fambrini e Fragoso-Cesar, 2006). Estudos estratigráficos de fácies, paleoambientes e sistemas deposicionais conduziram à subdivisão do Grupo Santa Bárbara na Sub-bacia Camaquã Oriental em duas unidades (Fambrini, 2003; Fambrini e Fragoso-Cesar, 2006; Fambrini et al., 2011):

1. Formação Passo da Capela, unidade formada por turbiditos de leques subaquosos;

2. Formação Rincão dos Mouras, unidade constituída por arenitos e conglomerados de leques aluviais e sistemas fluviais entrelaçados.

A Formação Passo da Capela apresenta a maior espessura já verificada dentro do Grupo Santa Bárbara, alcançando cerca de 4.000 m na Sub-bacia Camaquã Oriental. A principal associação litofaciológica compreende conglomerados e arenitos grossos depositados por fluxos gravitacionais de massa subaquosos e arenitos e ritmitos gerados por correntes de turbidez, representativos de ambiente de leques subaquosos, provavelmente lacustres. Esses depósitos de leques intercalam-se com arenitos e ritmitos de ambiente lacustre. A Formação Passo da Capela apresenta, ainda, intercalações de dois níveis de sismitos (sensu Seilacher, 1969; Mills, 1983; Vittori et al., 1991), indicativos de atividade tectônica sin-sedimentar. A Formação Rincão dos Mouras (até $2.000 \mathrm{~m}$ ), com correlatos em todas as sub-bacias (Fambrini, 2003), tais como as formações Pedra do Segredo (Fambrini et al., 2006; Marconato et al., 2014), na Sub-bacia Camaquã Ocidental, e Rincão dos Mouras, na Sub-bacia Camaquã Central (Fambrini et al., 2005, 2007), constitui-se de conglomerados e arenitos conglomeráticos depositados principalmente por sistemas de leques aluviais proximais a distais dominados por processos de enchentes em lençol que passam para depósitos fluviais de rios entrelaçados de alta energia. Dessa forma, a Formação Rincão dos Mouras e seus correlatos marcam a compartimentação tectônica da Bacia do Camaquã em sub-bacias por meio do soerguimento de altos internos. Fambrini e Fragoso-Cesar (2006) reconheceram três sequências deposicionais na Sub-bacia Camaquã Oriental com base nos preceitos de Vail et al. (1977). A Sequência 1 é composta principalmente de turbiditos arenosos indicativos de trato transgressivo, enquanto a Sequência 2 é constituída por sistemas de leques subaquosos representativos do trato regressivo, sobrepostos por uma sucessão lacustre com turbiditos de águas rasas trato transgressivo. Já a Sequência 3 marca a reorganização tectônica da Bacia do Camaquã, que passa a ser individualizada em sub-bacias separadas pelo alto de embasamento da Serra das Encantadas na Sub-bacia Camaquã Oriental, configurando trato regressivo forçado. Neste trabalho, o termo sub-bacia é empregado como um compartimento estrutural tal como encontrado hoje.

Análises de proveniência e paleocorrentes, objetivos principais deste trabalho, constituem ferramentas fundamentais na análise e compreensão da evolução tectônica de bacias, assim como contribuem significativamente para a 


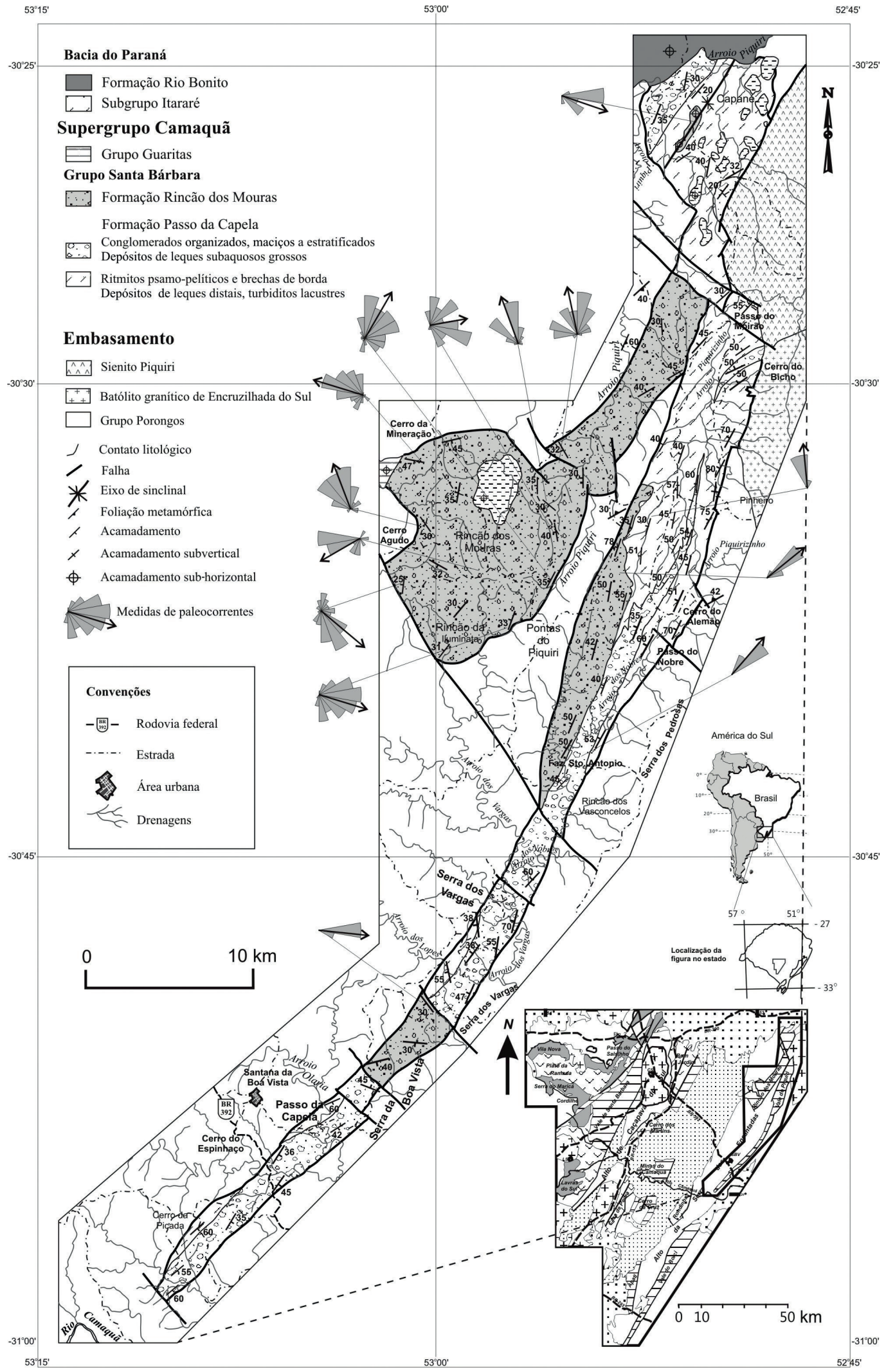

Fonte: modificada de Fambrini e Fragoso-Cesar (2006).

Figura 2. Mapa geológico do Grupo Santa Bárbara na Sub-bacia Camaquã Oriental com medidas de paleocorrentes efetuadas. 
reconstrução da história tectônica global (Dickinson, 1988; Miall, 2000). Essas análises, se integradas a análises de fácies e sistemas deposicionais, assim como a estudos petrográficos e de diagênese dos sedimentos, possibilitam caracterizar as áreas fonte de sedimentos para uma bacia, tal como o caso da Sub-bacia Camaquã Oriental. Portanto, propõe-se neste artigo um modelo de evolução de altos estruturais durante o preenchimento de uma bacia rifte maior, a Bacia do Camaquã, posteriormente separada em sub-bacias, tal como se observa atualmente.

\section{MATERIAIS E MÉTODOS}

A técnica de análise estratigráfica de proveniência e paleocorrentes foi empregada para a interpretação tectônica e paleogeográfica das unidades litoestratigráficas. Ela compreendeu estudos conjugados de análises de fácies, proveniência, paleocorrentes, petrografia e sistemas deposicionais. A partir da caracterização de fácies (e.g. Walker, 1992; Schanley e McCabe, 1994; Reading, 1996; Miall, 1988; James e Dalrymple, 2010), foram discriminados os diversos litotipos presentes que, posteriormente agrupados em associações de fácies, possibilitaram compor os ambientes deposicionais das rochas sedimentares para, então, considerá-las em um contexto de sistemas deposicionais.

As análises de proveniência foram realizadas em conglomerados e arenitos conglomeráticos, ao nível macroscópico em afloramentos, e na matriz de arenitos e conglomerados, ao nível microscópico. Nos afloramentos, compreendeu a contagem de todos os clastos componentes em uma malha predefinida segundo método aplicado por Fambrini (1998). A análise de proveniência, no arcabouço de conglomerados e arenitos conglomeráticos, foi implementada inicialmente pela estimativa visual da proporção dos constituintes maiores que $1 \mathrm{~cm}$ e posterior contagem aleatória (randomanalysis) de 100 clastos em cada localidade verificada (Nilsen, 1969; Graham, 1988; Ibbeken e Schleyer, 1991; Fambrini, 1998; Concoran e Mueller, 2002). Foram escolhidas, arbitrariamente, dimensões superiores a $1 \mathrm{~cm}$ com vistas a abranger a maior variação granulométrica possível. Para tanto, procedeu-se à identificação da litologia dos clastos e sua contagem. Cada porção do estrato ou do afloramento escolhida aleatoriamente era exaustivamente explorada, tentando-se obter o mínimo de 50 clastos pesquisados. Em afloramentos de dimensões reduzidas, ou sem exposições favoráveis, empreendeu-se a contagem sumária aleatória na tentativa de se alcançar o número mínimo. Já em afloramentos mais amplos - pedreiras, cortes de estrada, exposições naturais generosas e encostas de morros - dividiu-se a exposição por ciclos sedimentares (camadas) ou bancadas (pedreiras) para facilitar a tarefa, procedendo-se à contagem por nível escolhido e respeitando a estratigrafia.
As análises de paleocorrentes seguiram as recomendações de Potter e Pettijohn (1977), Miall (1977, 1978), Selley (1987, 2000), Tucker (1989), Walker e James (1992), Ghibaudo (1992), Coimbra et al. (1992), Assine (1994), Reading (1996), Boiano (1997) e Miall (2000).O estudo de paleocorrentes foi realizado por meio de medidas em:

1. estratos cruzados tabulares e/ou acanalados em arenitos e conglomerados;

2. imbricações de clastos em conglomerados com base no sentido do caimento do plano $a b$ e a posição dos eixos $b$ ("largura" ou eixo intermediário) ou $a$ (eixo paralelo à maior dimensão ou comprimento dos clastos) quanto à corrente;

3. variações de fácies e de granulometria.

\section{LITOESTRATIGRAFIA E PALEOCORRENTES}

Considerando-se critérios litoestratigráficos, no Grupo Santa Bárbara na Sub-bacia Camaquã Oriental são reconhecidas duas unidades mapeáveis na escala 1:25.000. A Formação Passo da Capela é formada por brechas, conglomerados e arenitos de leques subaquosos e turbiditos lacustres e está situada abaixo da Formação Rincão dos Mouras, constituída por conglomerados e arenitos grossos a conglomeráticos aluviais, sobreposta.

\section{Formação Passo da Capela}

Na Sub-bacia Camaquã Oriental, essa unidade apresenta a maior espessura já verificada dentro do Grupo Santa Bárbara, superando $4.000 \mathrm{~m}$ no Vale do Piquiri (Fambrini, 2003). A Formação Passo da Capela, conforme aqui definida, compreende os depósitos eminentemente siliciclásticos subaquáticos que afloram no Vale do Piquiri (Figura 2) e se situam estratigraficamente abaixo dos arenitos e conglomerados aluviais da Formação Rincão dos Mouras por discordância erosiva (Fambrini e Fragoso-Cesar, 2006).

A unidade exibe exposições desde a região em torno da cidade de Santana da Boa Vista, a sul, até a região de Capané, a norte (Figura 2). A localidade-tipo eleita para a unidade é um excelente afloramento natural em uma antiga passagem do arroio Olaria conhecida como Passo da Capela, localizada nas proximidades da cidade mencionada. No local, encontram-se tanto os arenitos e ritmitos quanto os conglomerados e arenitos grossos descritos e reconhecidos para a formação.

Os trabalhos de mapeamento geológico, descrição litológica, análise estratigráfica de fácies, proveniência e paleocorrentes e análise petrográfica realizados na Sub-bacia Camaquã Oriental, nas regiões do Vale do Piquiri/Rincão dos Mouras/Capané, permitiram a separação da Formação Passo da Capela nessa sub-bacia em três associações de fácies: Associação de Fácies 1, Associação de Fácies 2 e Associação de Fácies 3, que se relacionam de maneira 
proximal a distal. A Tabela 1 expõe as principais fácies identificadas na Formação Passo da Capela.

\section{Associação de Fácies 1}

A Associação de Fácies 1 aflora na região do curso médio do Arroio dos Nobres, além de serem observadas isoladas exposições na localidade do Passo da Capela e próximas ao Cerro da Picada (Figura 2). A unidade consiste basicamente de arenitos e ritmitos formados pela intercalação de arenitos finos maciços a laminados com siltitos laminados dispostos em camadas rítmicas tabulares de grande continuidade lateral e espessura, que perfazem profundidades entre 1.000 e 1.500 m (Tabela 1). Nessa sucessão interpõem-se, em seus níveis basais, quatro camadas de tufitos félsicos e, em dois níveis estratigráficos, que marcam limites de sequências, intervalos de depósitos interpretados como sismitos. As fácies predominantes são de arenitos finos a muito finos, micáceos, maciços (fácies Am) a laminados (fácies Al) e bem litificados (Fambrini e Fragoso-Cesar, 2006).

Tabela 1. Análise das fácies encontradas na Formação Passo da Capela no Vale do Piquiri.

\begin{tabular}{|c|c|c|c|}
\hline Código & Fácies & Descrição & Mecanismo deposicional \\
\hline Am & $\begin{array}{l}\text { Arenitos } \\
\text { finos maciços }\end{array}$ & $\begin{array}{c}\text { Arenitos finos maciços, localmente variando para } \\
\text { arenito médio. As camadas tabulares individuais de } \\
\sim 15 \mathrm{~cm} \text { de espessura encontram-se bem litificadas } \\
\text { e possuem grande extensão lateral. O topo e a base } \\
\text { podem, ocasionalmente, estar ondulados }\end{array}$ & $\begin{array}{l}\text { Depósitos de corrente de turbidez } \\
\text { subaquática, similares aos } \\
\text { dos arenitos do horizonte A da } \\
\text { sequência de turbiditos clássicos } \\
\text { de Bouma (1962) }\end{array}$ \\
\hline $\mathrm{Al}$ & $\begin{array}{l}\text { Arenitos muito } \\
\text { finos laminados }\end{array}$ & $\begin{array}{c}\text { Arenitos muito finos laminados, siltosos } \\
\text { e pouco argilosos, ocasionalmente com } \\
\text { delgadas películas de argila (mud drapes), } \\
\text { dispostas paralelamente à laminação. } \\
\text { As camadas possuem espessura média de } 7 \mathrm{~cm}\end{array}$ & $\begin{array}{c}\text { Análogo ao dos arenitos do } \\
\text { horizonte B da sequência de } \\
\text { turbiditos clássicos de Bouma } \\
\text { (1962). Depositados sob regime de } \\
\text { fluxo inferior ou superior }\end{array}$ \\
\hline $\mathrm{SI}$ & Siltitos laminados & $\begin{array}{l}\text { Siltitos com laminação plano-paralela, organizados } \\
\text { em camadas de } 5 \mathrm{~cm}\end{array}$ & $\begin{array}{l}\text { Material em suspensão das } \\
\text { correntes de turbidez }\end{array}$ \\
\hline $\mathrm{Ag}$ & $\begin{array}{l}\text { Arenitos finos } \\
\text { com grânulos }\end{array}$ & $\begin{array}{c}\text { Arenitos finos com grânulos e } \\
\text { pequenos seixos. Por vezes contêm } \\
\text { delgadas películas de argila (mud drapes) }\end{array}$ & $\begin{array}{l}\text { Nesse estágio, a corrente de } \\
\text { turbidez carrega os sedimentos } \\
\text { muito finos a grânulos }\end{array}$ \\
\hline Acg & $\begin{array}{l}\text { Arenitos } \\
\text { conglomeráticos }\end{array}$ & $\begin{array}{l}\text { Arenitos conglomeráticos com grânulos e } \\
\text { pequenos seixos, matriz de arenito médio } \\
\text { a grosso. Estratificação plano-paralela }\end{array}$ & $\begin{array}{l}\text { Indicam o início da perda de } \\
\text { competência dos fluxos turbidíticos }\end{array}$ \\
\hline $\mathrm{Ce}$ & $\begin{array}{l}\text { Conglomerados } \\
\text { com estratificação } \\
\text { plano-paralela }\end{array}$ & $\begin{array}{l}\text { Conglomerados polimíticos, organizados em } \\
\text { camadas tabulares de grande extensão lateral, } \\
\text { sustentados por arcabouço, com granulometria } \\
\text { de seixo a calhau ( } \phi_{\text {máx }}=10 \mathrm{~cm} \text { ), cujos clastos são } \\
\text { subangulosos a subarredondados. Matriz de arenito } \\
\text { grosso a médio e estratificação plano-paralela }\end{array}$ & $\begin{array}{l}\text { Depósitos de fluxos } \\
\text { canalizados, localizados } \\
\text { nas porções intermediárias } \\
\text { de leques subaquosos }\end{array}$ \\
\hline $\mathrm{Cm}$ & $\begin{array}{l}\text { Conglomerados } \\
\text { maciços }\end{array}$ & $\begin{array}{c}\text { Conglomerados sustentados por arcabouço, } \\
\text { maciços, com fragmentos em geral subangulosos } \\
\text { variando de seixo a matacão (até 1,3 m), mal } \\
\text { selecionados. A matriz é mal selecionada, grossa, } \\
\text { com grânulos subangulosos. A grande dimensão dos } \\
\text { clastos é característica }\end{array}$ & $\begin{array}{l}\text { Depósitos de fluxos de detritos, } \\
\text { localizados nas porções proximais } \\
\text { de leques subaquosos }\end{array}$ \\
\hline Ams & $\begin{array}{l}\text { Arenitos maciços } \\
\quad \text { silicificados }\end{array}$ & $\begin{array}{l}\text { Arenitos muito finos, maciços, muito silicificados, } \\
\text { em camadas individuais de } \sim 50 \mathrm{~cm} \text {, de grande } \\
\text { continuidade lateral }\end{array}$ & $\begin{array}{c}\text { Depósitos associados às correntes } \\
\text { de turbidez, posteriormente } \\
\text { silicificados }\end{array}$ \\
\hline Tf & Tufitos & $\begin{array}{l}\text { Rocha vulcânica, de textura afanítica, com vidro } \\
\text { vulcânico, piroclastos e minúsculos fragmentos líticos }\end{array}$ & $\begin{array}{l}\text { Associado à atividade vulcânica } \\
\text { explosiva }\end{array}$ \\
\hline$A c$ & $\begin{array}{l}\text { Arenitos argilosos } \\
\text { com laminações } \\
\text { cavalgantes }\end{array}$ & $\begin{array}{l}\text { Arenitos muito finos argilosos, em camadas } \\
\text { individuais, de grande continuidade lateral e } \sim 4 \\
\text { cm de espessura, formando pacotes de até } 25 \\
\text { cm. No topo há marcas onduladas assimétricas, } \\
\text { apresentando internamente laminações cruzadas } \\
\text { (climbing ripples) de crista reta }\end{array}$ & $\begin{array}{l}\text { Depósitos de correntes subaquosas } \\
\text { onde atuam conjuntamente } \\
\text { processos de deposição de } \\
\text { material de tração e decantação }\end{array}$ \\
\hline
\end{tabular}

Fonte: modificada de Fambrini (2003) e de Fambrini e Fragoso-Cesar (2006). 
Por vezes, o topo e/ou a base podem estar ondulados em razão da associação com arenitos finos com laminação cruzada cavalgante de base reta (formada a partir de correntes) da Fácies Ac. Os arenitos maciços apresentam camadas individuais mais espessas (até $30 \mathrm{~cm}$ ) e podem estar silicificados, fato que sustenta pequenas cristas no terreno, Já os arenitos laminados são siltosos, pouco argilosos, por vezes contendo delgadas películas de argila (mud drapes) subparalelas à laminação plano-paralela conspícua, de espessura centimétrica (da ordem de 2 a $8 \mathrm{~cm}$ ).

A Associação de Fácies 1 apresenta intercalações de lentes rudáceas delgadas (espessura máxima de aproximadamente $50 \mathrm{~m}$ ) restritas à base da unidade, constituídas por brechas e, subordinadamente, conglomerados sustentados por arcabouço, compostos de clastos muito angulosos e tabulares de esfericidade baixa, da granulometria seixo até calhau, espalhados pela matriz mal selecionada muito fina a grossa, sem organização alguma evidente (Figura 3). Petrograficamente, os clastos da brecha são de filito sericítico (maioria), quartzito fino, milonito, gnaisse, granito e quartzo de veio (Fambrini, 2003), conforme consta na Figura 3. Esses depósitos rudáceos lenticulares basais, cartográfica e volumetricamente pouco expressivos, ocorrem como lentes de espessura reduzida (50 $\mathrm{m}$ nas proximidades do Cerro do Alemão) ao longo do Vale do Piquiri, nas regiões de Santana da Boa Vista e em torno do Cerro do Bicho, e a sul do Rio Camaquã, na borda leste da ocorrência do Arroio Boici (Sayeg et al., 1992; Sayeg, 1993; Fambrini e Fragoso-Cesar, 2006), como pode ser observado na Figura 1B.
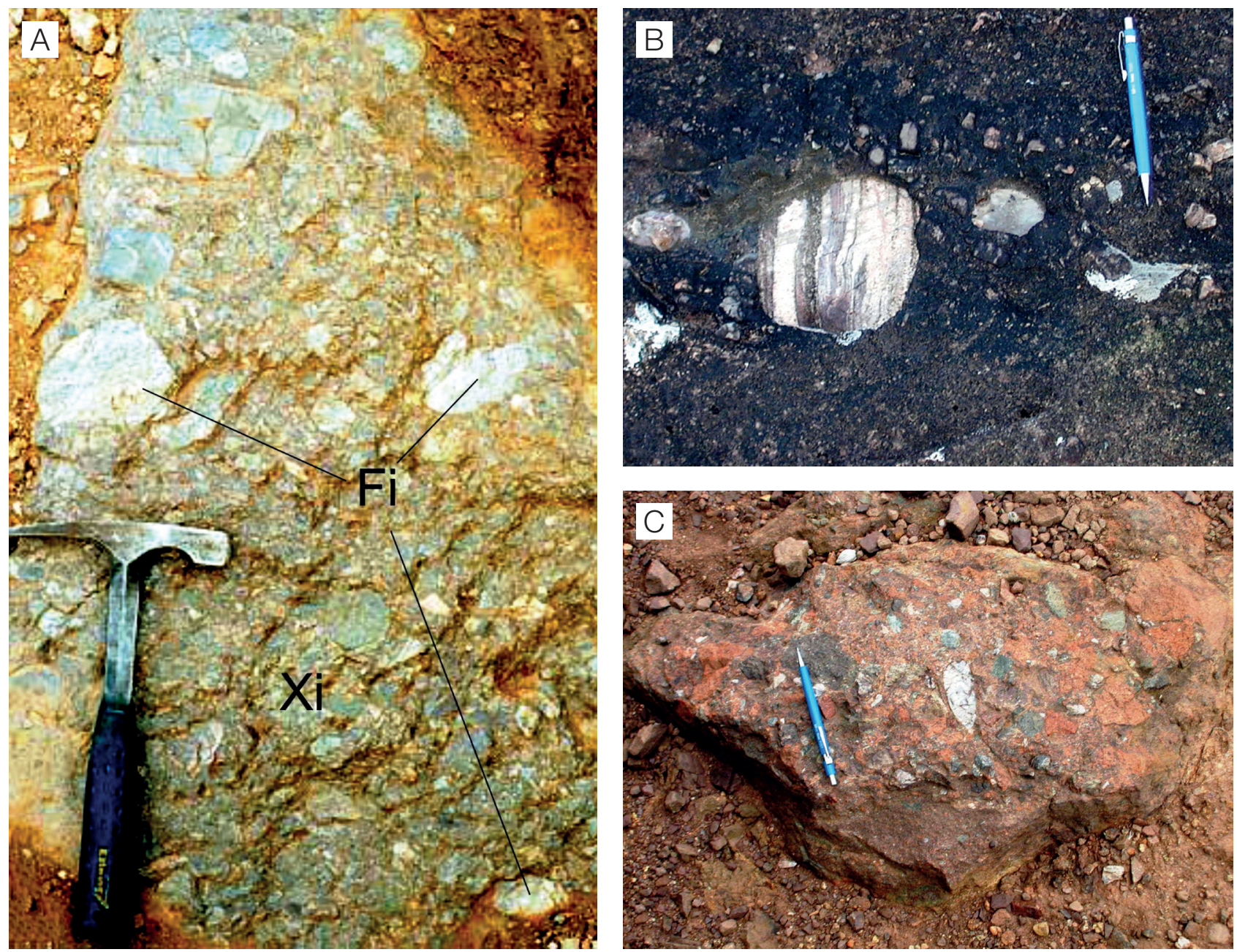

Fi: filitos sericíticos; Xi: xistos verdes

Figura 3. Fragmentos de rochas do embasamento adjacente presentes nas brechas da Associação de Fácies 1 da Formação Passo da Capela. (A) detalhe das brechas junto ao contato com o Complexo Porongos, onde se destacam seixos de filitos sericíticos e de xistos verdes derivados dessa unidade de embasamento; (B) fragmentos de milonitos do embasamento adjacente do Complexo Porongos; (C) fragmentos de filitos sericíticos, metarriolitos, milonitos, quartzo de veio, xistos verdes e de rochas metamórficas do Complexo Porongos. 
As delgadas intercalações de arenitos finos maciços, laminados e com laminações cruzadas cavalgantes e siltitos foram interpretadas como depósitos gerados por correntes de turbidez de baixa densidade em corpo lacustre, segundo preceitos de Lowe (1982), consistindo de turbiditos clássicos (sensu Walker, 1992; James e Dalrymple, 2010) relacionados a uma sucessão retrogradacional. As brechas lenticulares basais, em razão da associação com os turbiditos, sugerem condições subaquáticas de deposição, provavelmente nas partes proximais de um leque subaquoso lacustre.

\section{Associação de Fácies2}

A Associação de Fácies 2 concentra-se na porção meridional e intermediária na região do Vale do Piquiri, em cotas mais elevadas ( 250 a $370 \mathrm{~m}$ ), mas também está presente na porção setentrional, em ocorrências isoladas na localidade do Passo do Moirão e nos flancos de estrutura sinclinal na região de Capané (Figura 2). Essa associação consiste em conglomerados maciços a estratificados (Figuras 4A a 4D), com intercalações subordinadas de arenitos conglomeráticos. Os conglomerados maciços (fácies $\mathrm{Cma}$ ) são sustentados por matriz e por arcabouço. Eles têm como característica a desorganização do depósito realçada pela diferença entre a matriz e os clastos do tamanho matacão, que atingem dimensão máxima de 3,20 m (Figuras 4E a 4H). A matriz é composta por uma mistura heterogênea de areia, silte e grânulos. Outra peculiaridade desses conglomerados é a abundância de fragmentos de rochas da própria bacia, em especial arenitos finos e médios e conglomerados das unidades sotopostas. Em uma ocorrência, anteriormente descrita e interpretada por Fragoso-Cesar (1984), encontra-se um grande fragmento de uma camada de arenito fino, com aproximadamente $8 \mathrm{~m}$ de diâmetro máximo e espessura em torno de $80 \mathrm{~cm}$, que, ao ser arrancado do fundo da bacia, dividiu-se em diversas partes com dimensão máxima de $1,30 \mathrm{~m}$, cujos fragmentos, se somados, ultrapassam $8 \mathrm{~m}$ de comprimento (Figura 4G).

Os conglomerados, expostos na porção nordeste da bacia na região a leste de Capané (e.g. Passo do Moirão, vide Figura 5), encontram-se em contato por falhas normais com o Sienito Piquiri (Tessari e Picada, 1966), do qual provém boa parte dos detritos verificados em seu arcabouço. Os conglomerados são oligomíticos, sustentados pelo arcabouço (clastos arredondados a subangulosos da granulometria seixo a matacão, $\phi_{\text {máx. }}=76 \mathrm{~cm}$ ), com predomínio da granulometria calhau, grosseiramente estratificados por gradação, com matriz de arenito grosso com grânulos, mal selecionada, de coloração róseo-avermelhada (Figura 5). Os clastos são arredondados a subangulosos, com predomínio de subarredondados. $\mathrm{O}$ arredondamento verificado nos clastos deve ser função direta de sua natureza, ou seja, litologias graníticas e sieníticas que geralmente já são erodidas da área fonte na forma arredondada devido, talvez, ao fenômeno da esfoliação esferoidal. Entretanto, a natureza mal selecionada do depósito, com grande variação na granulometria dos clastos, a pouca organização encontrada e a ausência de imbricações sugerem ambiente de leque subaquoso de caráter proximal, possivelmente gerado em regime de fluxo de detritos, em virtude da associação com os depósitos de turbiditos. Em direção ao topo, os conglomerados mostram certa estratificação plano-paralela em razão da granodecrescência ascendente, embora preservem a má seleção característica do depósito, ocorrendo uma dispersão maior dos clastos, porém mantendo a granulometria matacão e calhau. Acima, intercalam-se níveis de arenitos conglomeráticos e arenitos com seixos. Para o topo, os arenitos passam a ser médios com grânulos, e alguns, seixos esparsos, em camadas decimétricas (40 a $60 \mathrm{~cm}$ ). Como estruturas sedimentares, destacam-se, além da estrutura maciça e da estratificação plano-paralela, estratificações cruzadas acanaladas de pequeno porte nos arenitos (pouco frequentes).

Os conglomerados maciços (fácies $\mathrm{Cmc}$ ) sustentados por arcabouço (fragmentos $>50 \%$, conforme Collinson e Thompson, 1989) são extremamente mal selecionados e possuem clastos predominantemente da granulometria calhau a matacão, que localmente alcançam diâmetro superior a $1 \mathrm{~m}\left(\phi_{\text {máx. }}=1,3 \mathrm{~m}\right)$. Os clastos alternam-se de angulosos a subarredondados, com predomínio dos primeiros (inclusive com arestas preservadas), e possuem, em sua maioria, baixa esfericidade. As camadas de conglomerados são métricas e aparentemente tabulares. Nelas destacam-se matacões subangulosos de arenitos finos, por vezes silicificados, de aspecto tabular, alinhados em meio à estrutura maciça da rocha. Esses depósitos situam-se preferencialmente nas porções proximais.

Devido às características intrínsecas dos depósitos, tais como desorganização, má seleção, coexistência de grânulos com matacões de até 3,20 m - muito grossos, de acordo com Blair e McPherson, 1999; Terry e Goff, 2014 —, presença de mistura heterogênea de areia, silte e grânulos como matriz, e ausência de estruturas trativas, eles foram interpretados como originados a partir de fluxos de detritos não coesos (debris flow), de acordo com preceitos de Lowe (1982), Nilsen (1985) e Mulder e Alexander (2001). Com isso, fragmentos de grandes dimensões puderam ser transportados em suspensão, em razão da concentração de uma matriz representada pela mistura intersticial de água e sedimentos finos (fluxo hiperconcentrado).

Nessa unidade, destacam-se, ainda, conglomerados estratificados e intercalações de arenitos conglomeráticos e até arenitos finos que incorporam conjuntos de camadas com granodecrescência ascendente e lateral conspícua. Os conglomerados estratificados (fácies Ce) são organizados, polimíticos, sustentados por arcabouço, dispostos em pacotes decimétricos a métricos ( $70 \mathrm{~cm}$ a $1,5 \mathrm{~m}$ de espessura), com estratificação plano-paralela denotada por gradação no tamanho ou na seleção dos clastos, e estratificação cruzada acanalada de porte pequeno. Os fragmentos encontram-se 

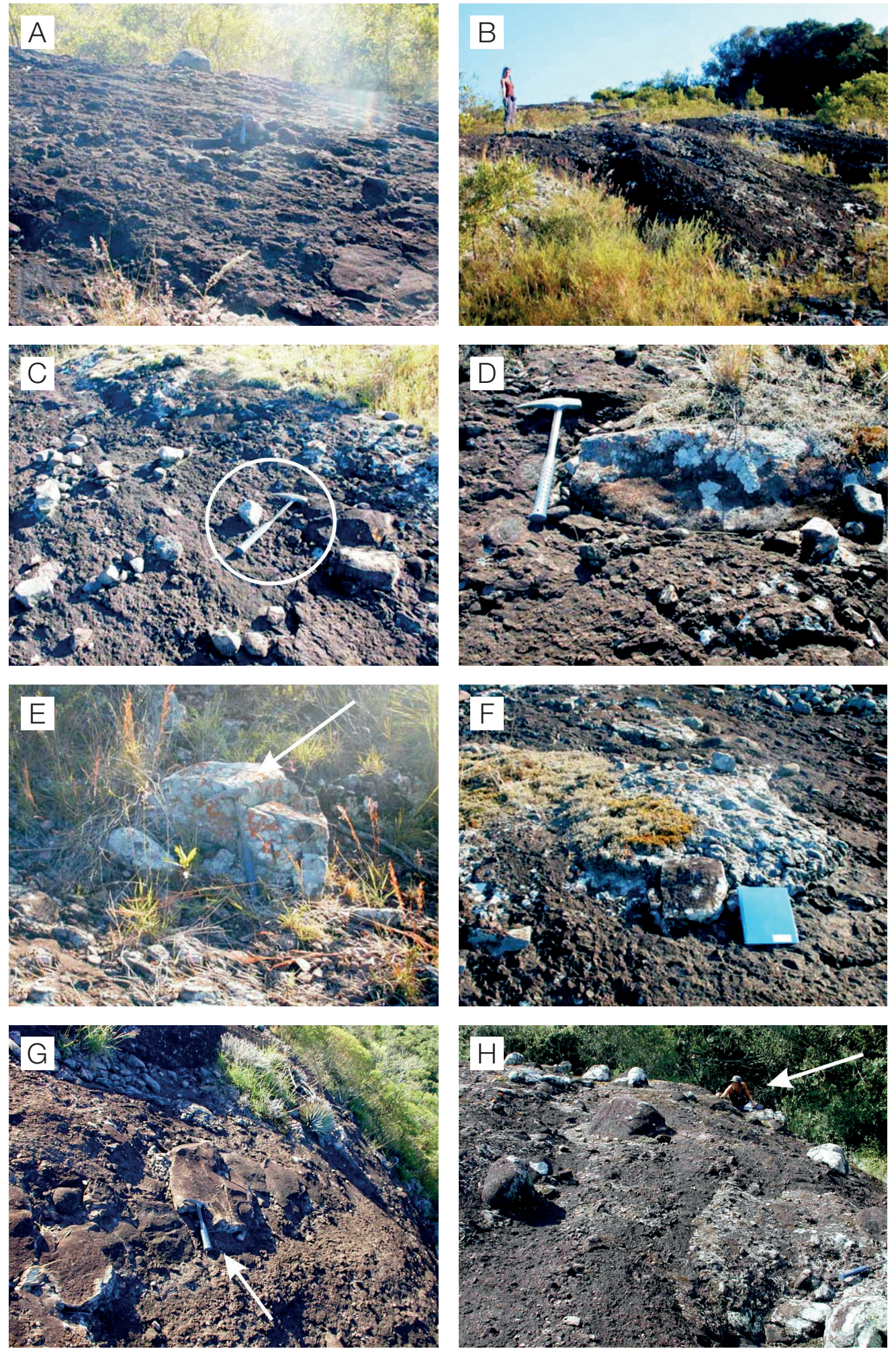

Figura 4. Conglomerados de leque subaquoso da Associação 2 da Formação Passo da Capela no Vale do Piquiri. (A) e (B) conglomerados estratificados tabulares (fácies Ce); (C) e (D) calhaus e matacões angulosos a subangulosos de arenitos nos conglomerados maciços (fácies $\mathrm{Cma}$ ); (E) detalhe de matacão de quartzito; (F) concentração de clastos nos conglomerados estratificados (principalmente arenitos); (G) megaclastos de arenitos que constituem uma camada de mais de $8 \mathrm{~m}$ de comprimento; $(\mathrm{H})$ conglomerados estratificados com diversos clastos de arenitos. Círculos e setas indicam escala. 
fortemente imbricados e variam em tamanho de seixo a matacão; ora são muito angulosos, ora subarredondados, e, em geral, com baixo grau de esfericidade. A matriz é mal selecionada e constituída por arenito grosso a médio, por vezes com grânulos, cujos grãos mostram-se angulosos a subarredondados, com predomínio de subangulosos. Como estruturas sedimentares destacam-se a estratificação plano-paralela e, localmente, estratificação cruzada do tipo acanalado. Nessa sucessão ocorrem, ainda, arenitos conglomeráticos (fácies Acg), maciços a estratificados, compostos por arenitos finos a grossos geralmente mal selecionados, dispostos em camadas que variam de 20 a $70 \mathrm{~cm}$. Como estruturas sedimentares nessa fácies ocorrem estratificação plano-paralela e, por vezes, estratificação cruzada tabular de pequeno porte. Tais características apontam para deposição em meio aquático com tração. Processos trativos são observados nas porções mediano-distais dos leques e sugerem a expansão radial dos fluxos de correntes, após abandonarem os canais nos quais se encontravam confinados pelas suas paredes, sobretudo no topo da associação. Os depósitos em questão são interpretados como originados por turbiditos de alta densidade (sensu Lowe, 1979, 1982).

Essa associação de fácies é interpretada como originada em ambiente subaquático (leque subaquoso) em posição proximal em relação à área fonte. Os conglomerados maciços indicam processos de sedimentação relacionados à participação de fluxos sedimentares de alta densidade (fluxos de detritos coesos) de acordo com Middleton e Hempton (1976), Lowe (1982) e Mulder e Alexander (2001). Por outro lado, os conglomerados estratificados com intercalações de arenitos conglomeráticos e arenitos representam turbiditos de alta densidade no sentido de Lowe (1982).
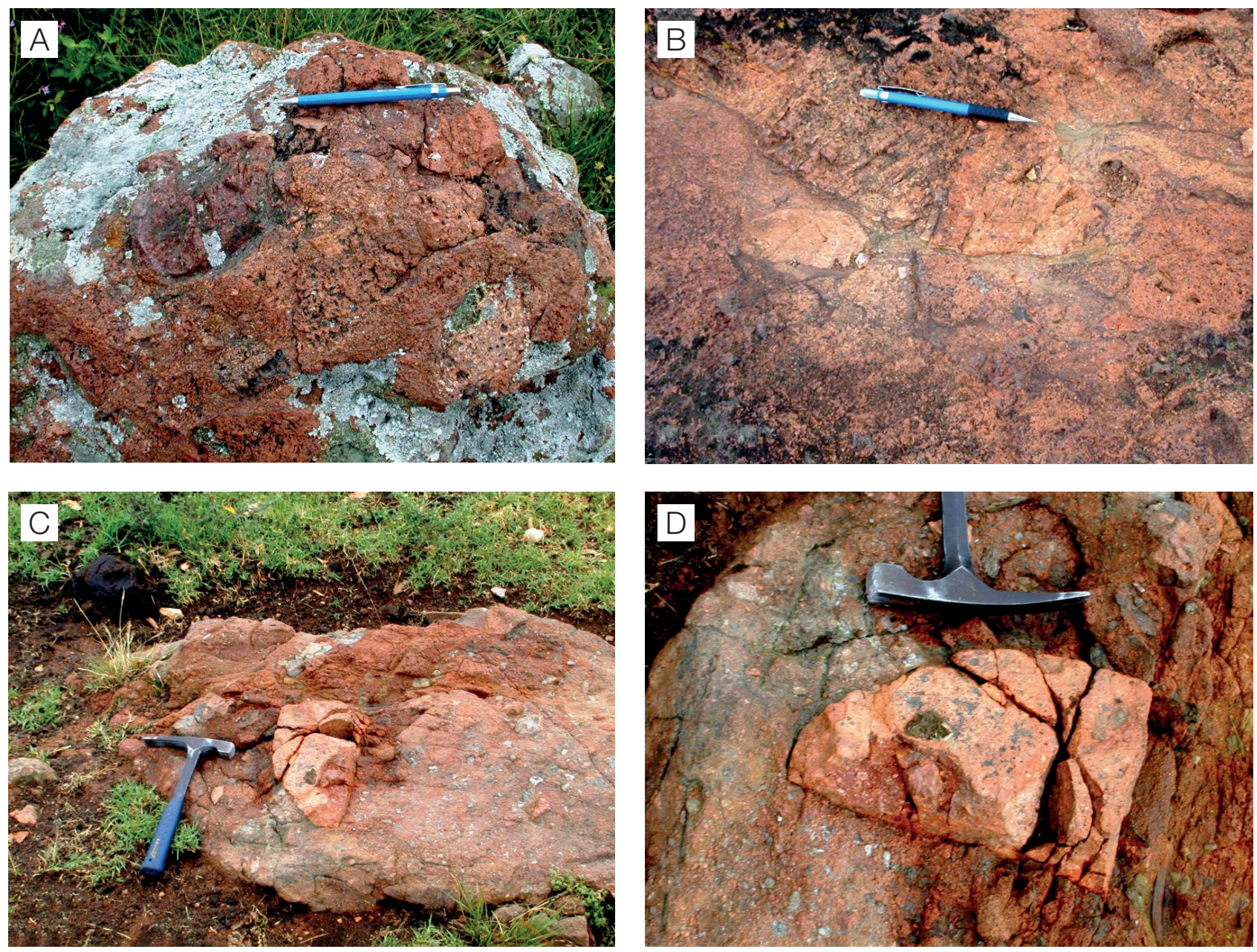

Fonte: modificado de Fambrini, 2003

Figura 5. Aspectos do arcabouço dos conglomerados da Formação Passo da Capela na Sub-bacia Camaquã Oriental. (A) brecha sedimentar no contato com o Sienito Piquiri; (B) matriz da brecha sedimentar; (C) clastos de sienitos e traquitos do arcabouço dos conglomerados da Formação Passo da Capela na localidade VP-37 (Passo do Moirão); (D) detalhe de clasto de traquito de C. 
Associação de Fácies 3

A Associação de Fácies 3 compreende intercalações de diversos corpos de arenitos com siltitos, de coloração castanha-avermelhada característica. Os arenitos maciços (fácies Am) são compostos por arenitos maciços, bem litificados, micáceos (placas de muscovita), dispostos em camadas tabulares centimétricas de grande continuidade lateral. Os arenitos finos laminados (fácies Al) são siltosos e pouco argilosos, e são encontrados dispostos em camadas delgadas de 2 a $8 \mathrm{~cm}$. Localmente, elas apresentam topo e/ou base ondulado. A fácies de arenitos com laminações cruzadas cavalgantes (fácies Ac) caracteriza-se por arenitos muito finos argilosos de espessura centimétrica $(4 \mathrm{~cm})$ que, internamente, apresentam abundantes laminações cruzadas cavalgantes (climbing ripples) de base reta. O topo das camadas, por vezes, apresenta marcas onduladas assimétricas (wave ripples). Os arenitos laminados possuem delgadas coberturas de lama (mud drapes) paralelas à laminação. A fácies de siltitos laminados (fácies $\mathrm{Sl}$ ) constitui-se de siltitos de coloração ocre com laminação plano-paralela conspícua, que se distribuem em camadas tabulares de grande continuidade lateral, atingindo, no máximo, $6 \mathrm{~cm}$ de espessura. Em decorrência da laminação plano-paralela, o empastilhamento das camadas é acentuado. De ocorrência subordinada, a fácies Ams compreende arenitos finos, ocasionalmente médios, maciços, muito silicificados, com cor marrom-acinzentada, que estão dispostos em camadas individuais muito espessas, variando de $50 \mathrm{~cm}$ a $1 \mathrm{~m}$, sendo responsáveis pelas pequenas cristas do relevo em meio aos ritmitos.

Essa associação representa sedimentação de turbiditos de baixa densidade, com a deposição de material arenoso sob tração, com a gradual desaceleração da corrente e, a seguir, material do tamanho argila e silte (heterolítico) com feições de tração e suspensão (Lowe, 1979, 1982), sugestivos de depósitos de overbank.

\section{Análise de Paleocorrentes}

De acordo com as diferentes interpretações paleoambientais dos depósitos do leque subaquoso do Vale do Piquiri, que, como última instância, refletem padrões distintos de paleocorrentes, esses puderam ser analisados separadamente por sucessão de depósito.

\section{Depósitos de fluxo de detritos da Associação de Fácies 1 de sistema de leque subaquoso}

Não foram encontradas estruturas para avaliar a dispersão dos sedimentos nesses depósitos. Entretanto, a variação de fácies mais finas na direção norte (rumo ao depocentro da bacia) sugere aporte sedimentar longitudinal ao eixo da bacia (Figura 2).

\section{Depósitos de turbiditos da Associação de Fácies 1 de sistema de leque subaquoso}

Utilizando-se das atitudes de estruturas associadas a transporte sedimentar por fluxos unidirecionais, presentes nos conglomerados e arenitos de turbiditos de alta densidade, foram coletadas 35 medidas de paleocorrentes com tendência preferencial para N-NE, coerente com a orientação geral, de SSW para NNE, das associações de fácies ali encontradas (Figura 6).

\section{Depósitos de turbiditos da Associação de Fácies 2 de sistema de leque subaquoso}

Nessa sucessão de arenitos finos e ritmitos foram medidos 78 planos de laminações cruzadas cavalgantes de base reta (por corrente), conforme Figura 7. As paleocorrentes coletadas em laminações cruzadas cavalgantes nos turbiditos revelaram uma direção de paleofluxo consistente para NNE, ou seja, longitudinal à orientação geral da Sub-bacia Camaquã Oriental no Vale do Piquiri. Tal padrão de paleocorrentes longitudinal às bordas da bacia é típico de depósitos de turbiditos e coerente com dados encontrados na literatura sobre o tema (e.g. Davies e Walker, 1974; Boiano, 1997).

\section{Depósitos de turbiditos da Associação de Fácies 3 de sistema de leque subaquoso}

Nos depósitos de turbiditos de leque distal foram medidos 69 planos de laminações cruzadas cavalgantes de base reta (por corrente), como pode ser observado na Figura 8. As análises de paleocorrentes evidenciam, em geral, sentido de paleofluxo variando entre os quadrantes $\mathrm{N}$ e NE. Esse conjunto de paleocorrentes demonstra padrão unidirecional e unimodal de dispersão, com sentido NE, longitudinal às bordas da bacia, característico de depósitos de correntes de turbidez (e.g. Davies e Walker, 1974; Boiano, 1997). Variações locais, com sentidos NW e NE, nas porções mediano-distais dos leques, podem indicar a expansão radial dos fluxos, após esses abandonarem os canais nos quais se encontravam confinados pelas suas paredes, sobretudo no topo da sucessão (Figura 8A). A Figura 2 apresenta mapa com a distribuição de paleocorrentes.

\section{Formação Rincão dos Mouras}

A Formação Rincão dos Mouras acha-se bem caracterizada em todas as sub-bacias nas quais ocorre o Grupo Santa Bárbara e, possivelmente, representa eventos de individualização dessas ocorrências (Fambrini et al., 2005, 2006, 2007; Fambrini e Fragoso-Cesar, 2006; Fambrini et al., 2011, 2014). Tais eventos foram responsáveis pela atual configuração das unidades na Bacia do Camaquã. A Formação Rincão dos 


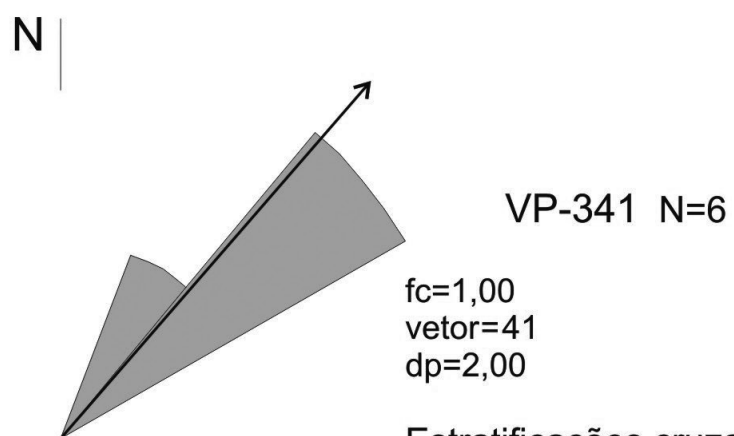

\section{Estratificações cruzadas tabulares de pequeno porte}

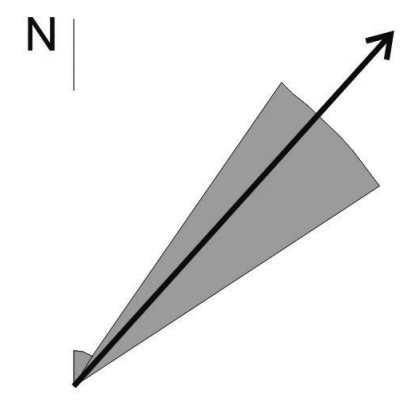

VP-272 $N=11$
$f c=0,99$
vetor $=42$
$d p=8,97$

Estratificações cruzadas tabulares e imbricações de clastos

$\mathrm{N}$

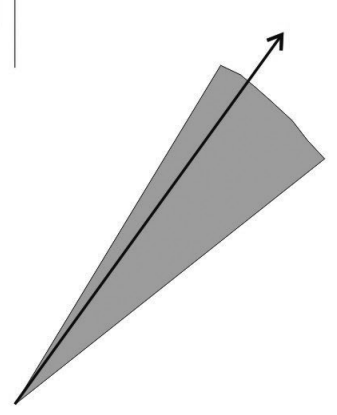

VP-244 N=5

$\mathrm{fC}=1,00$

vetor $=35$

$\mathrm{dp}=4,93$

Imbricações de clastos
VP-252 N=7

$\mathrm{fC}=0,54$

vetor $=50$

$\mathrm{dp}=65,55$

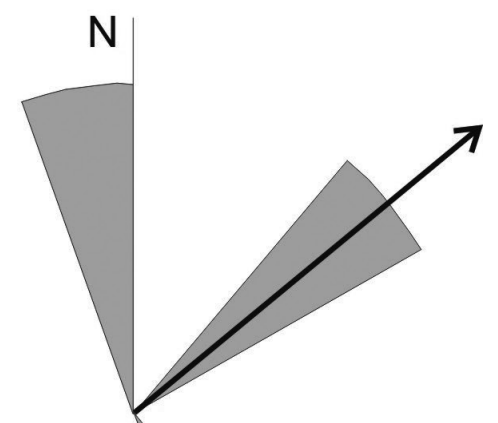

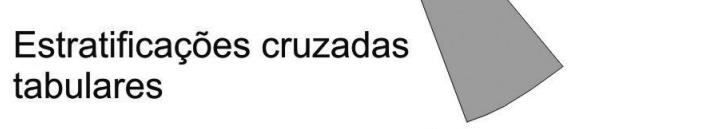

\section{Estratificaco}

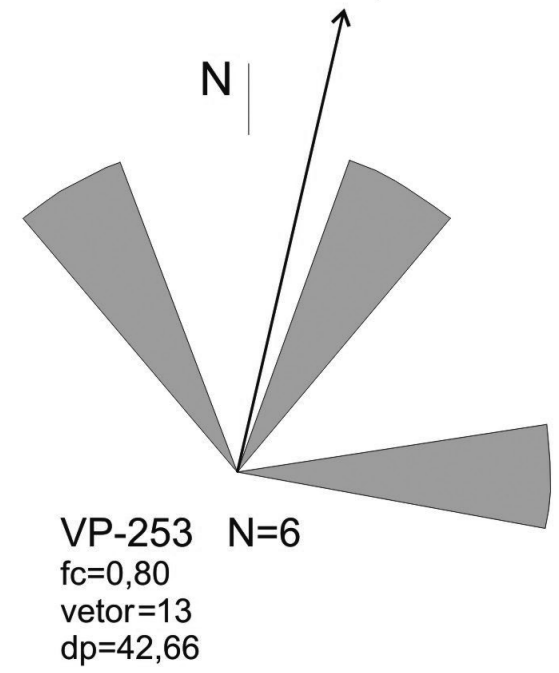

Estratificações cruzadas tabulares

N: número de medidas; dp: desvio-padrão; fc: fator de consistência; VP: ponto de coleta.

Figura 6. Padrão de dispersão de paleocorrentes de leque intermediário (arenitos e conglomerados) da Formação Passo da Capela no Vale do Piquiri. As medidas foram coletadas em estratificações cruzadas do tipo tabular e, subordinadamente, em imbricações de clastos alongados. 


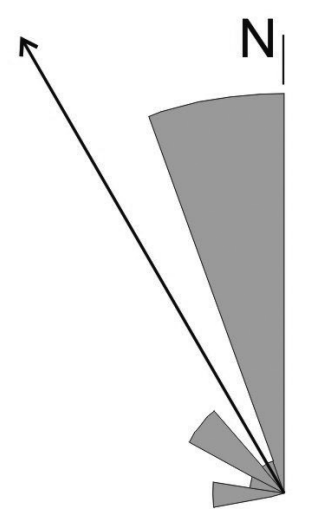

VP-291 $\mathrm{N}=28$

$\mathrm{fc}=0,31$

vetor $=345$

$\mathrm{dp}=28,88$

Laminações cruzadas cavalgantes

A

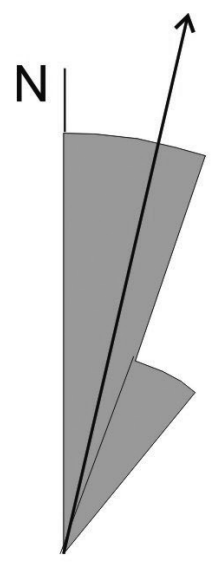
VP-291 $\quad \mathrm{N}=3$
$\mathrm{fC}=0,81$
vetor $=13$
$\mathrm{dp}=7,51$

\section{Marcas de sola}

$\mathrm{B}$

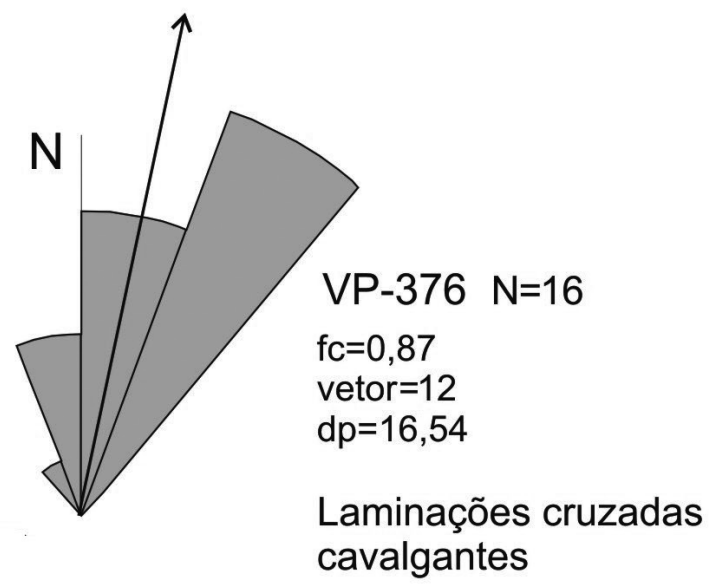

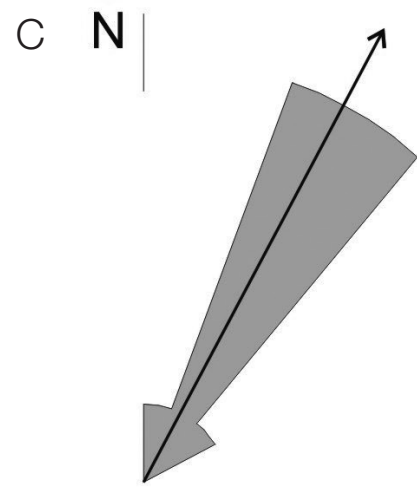

VP-217 $\mathrm{N}=07$

$\mathrm{fc}=0,87$

vetor $=28$

$\mathrm{dp}=12,88$

Laminações cruzadas cavalgantes

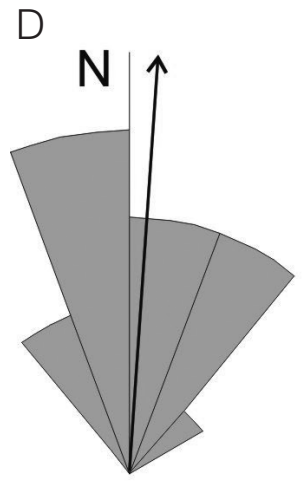
VP-257 $N=18$
$\mathrm{fc}=0,95$
vetor $=04$
$\mathrm{dp}=19,59$
Laminações cruzadas cavalgantes

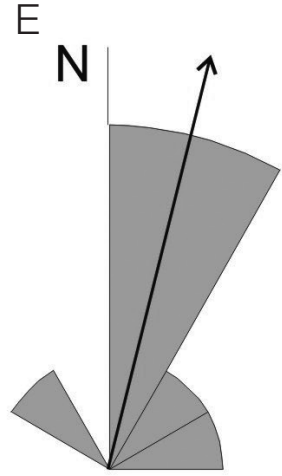
VP-316 $\mathrm{N}=06$
$\mathrm{fc}=0,80$ vetor $=14$
$\mathrm{dp}=41,25$
Laminações cruzadas cavalgantes

N: número de medidas; dp: desvio-padrão; fc: fator de consistência; VP: ponto de medida.

Figura 7. Padrão de dispersão de paleocorrentes dos turbiditos de leque intermediário e externo da Formação Passo da Capela no Vale do Piquiri. A coleta foi realizada em laminações cruzadas dos tipos comum e cavalgante. (A) diagramas de roseta de paleocorrentes em depósitos de turbiditos finos nas proximidades do contato com o embasamento; a diferença no padrão de dispersão refere-se ao tipo de estrutura medida e morfologia do leque; o diagrama da esquerda representa porções de overbank do leque, ao passo que o da direita, possível escavação de um canal subaquoso (marcas de sola); (B) e (C) diagramas de roseta de paleocorrentes de lobos arenosiltosos de leque externo (outer-fan lobe); (D) e (E) diagramas de roseta dos lobos de leque externo em posição estratigráfica superior a (B) e (C). 

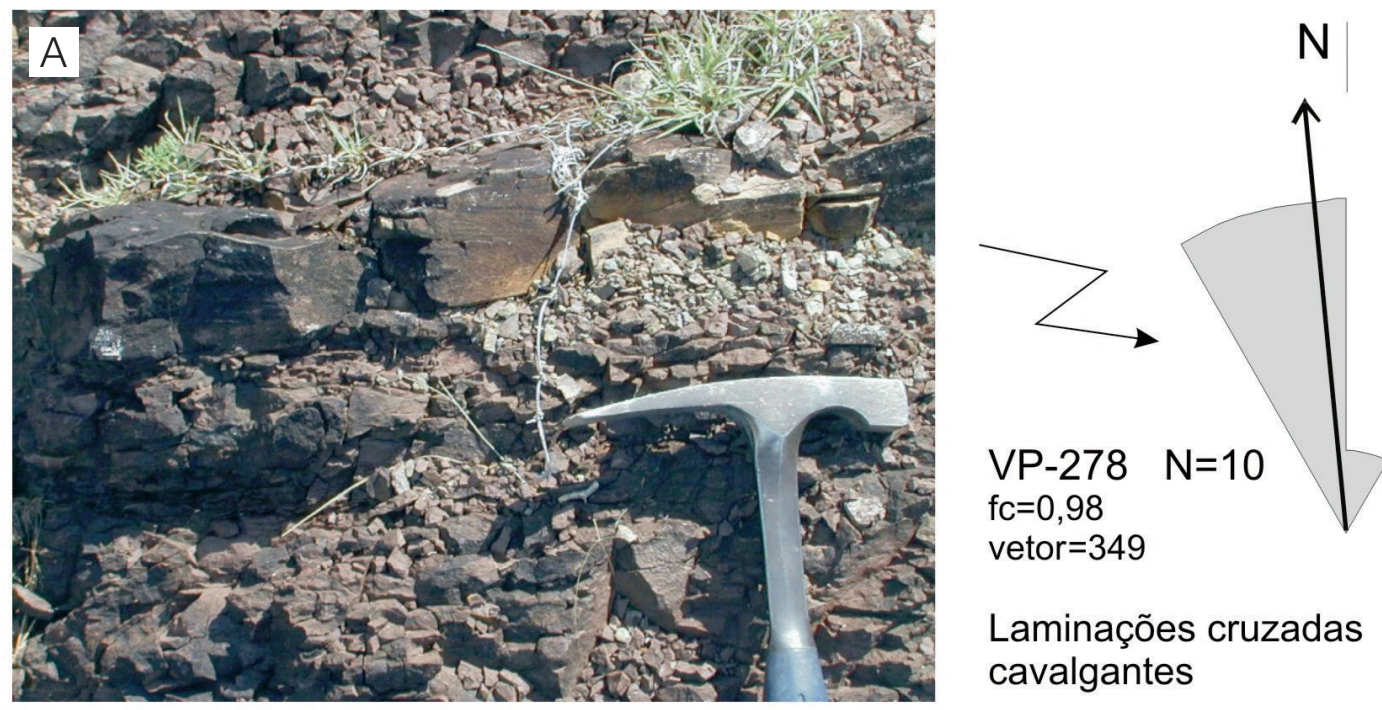

vetor $=349$

\section{Laminações cruzadas cavalgantes}

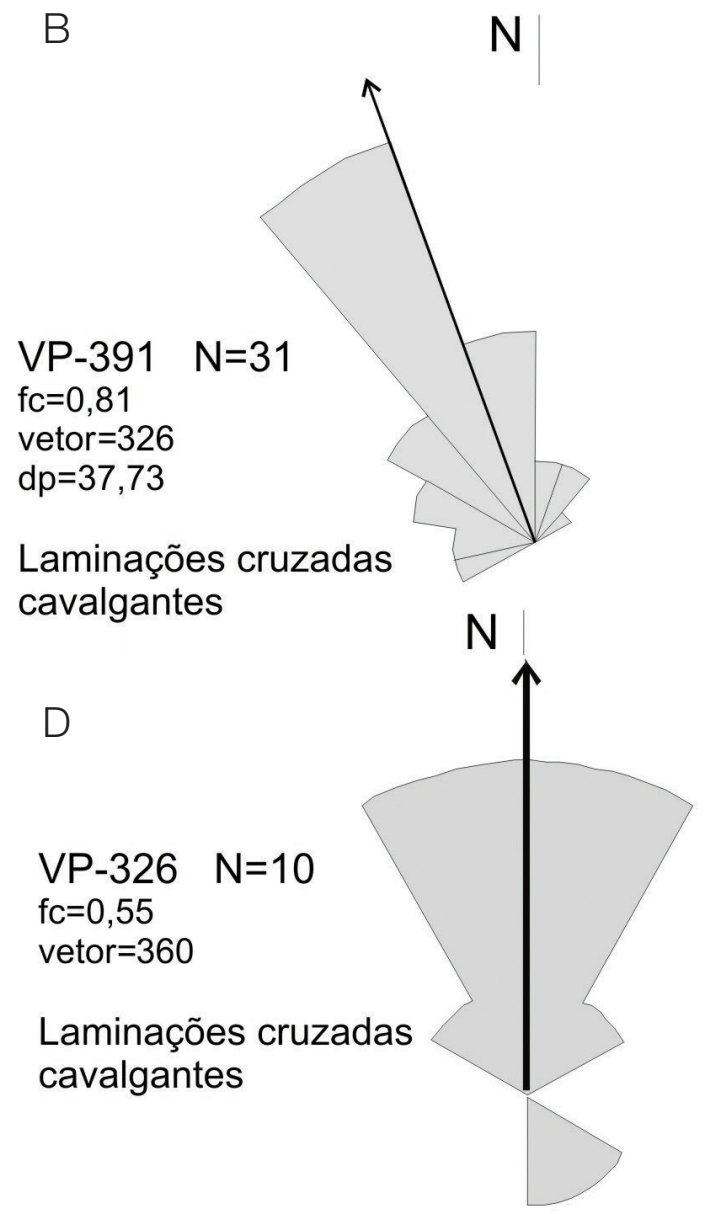

C N

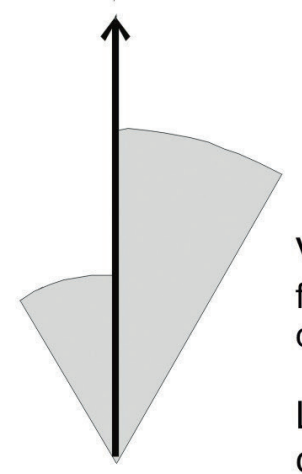

VP-139 N=12

$\mathrm{fc}=0,99$

$\mathrm{dp}=9,39$

Laminações cruzadas cavalgantes

cavalgantes
$\mathrm{N}$
E

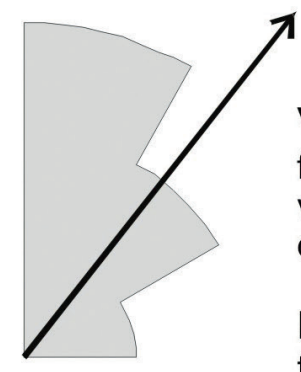

VP-365, $367 \quad N=6$
$f c=0,94$
vetor $=38$
$d p=21,76$

Estratificações cruzadas tangenciais na base

N: número de medidas; dp: desvio-padrão; fc: fator de consistência; VP: ponto de medida

Figura 8. Padrão de paleocorrentes dos turbiditos externos da Formação Passo da Capela. (A) exemplo de estrutura em que foram coletadas as medidas (no caso, laminação cruzada cavalgante do local VP-278, vide seta), que, como em (B), representam intervalo superior do leque; ( $\mathrm{C}$ a E) diagramas de roseta dos locais amostrados. 
Mouras abarca depósitos granodecrescentes interpretados como de origem aluvial. A unidade expõe-se em larga área da porção noroeste do Vale do Piquiri, nas escarpas do Rincão dos Mouras e em bloco abatido junto à Serra da Boa Vista, e nas nascentes do Arroio Piquiri, cuja continuidade é obstruída por alto de embasamento. A sucessão aluvial da Formação Rincão dos Mouras compreende associações de fácies de:

1. conglomerados (leques aluviais proximais a distais);

2. arenitos e arenitos conglomeráticos representativos de sistema fluvial entrelaçado (Figura 9), a seguir descritos.

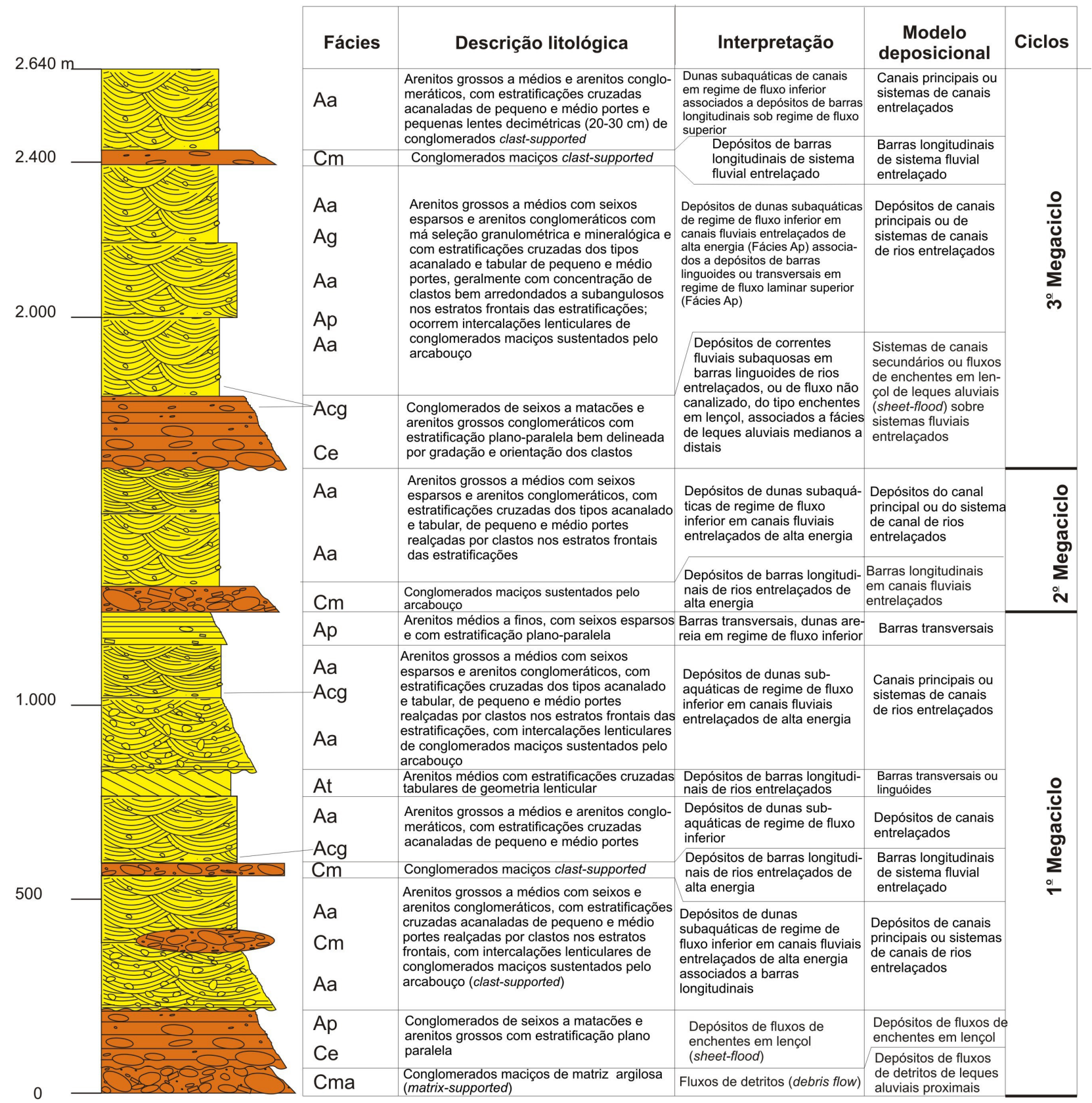

Ar Si A A A G S C M

Granulometria: Ar - argila, Si - silte, Af - areia fina, Am - areia média, Ag - areia grossa, G - grânulo, C - calhau, M - matacão

Aa: arenitos grossos a médios e arenitos conglomeráticos, com estratificação cruzada acanalada; Cm: conglomerados maciços; Ag: arenitos finos com grânulos; Ap: arenitos grossos a médios com estratificação plano-paralela; Acg: arenitos conglomeráticos; Ce: conglomerados com estratificação plano-paralela; At: arenitos com estratificação cruzada tabular; Cma: conglomerados maciços de matriz argilosa.

Figura 9. Seção colunar geral da Formação Rincão dos Mouras na região homônima. Observação de três megaciclos. Modelos deposicionais com base nos trabalhos de Miall $(1977,1981,1996,2014)$. 


\section{Associação de fácies de conglomerados}

Na porção inferior dessa sucessão $\left(1^{\circ}\right.$ megaciclo, Figura 9) aparecem conglomerados maciços oligomíticos sustentados por matriz (fácies $\mathrm{Cma}$ ), como pode ser visto na
Tabela 2. Ela é formada por argila e fragmentos detríticos de diversas formas e frações granulométricas, de ocorrência restrita a afloramentos isolados (Figura 9). $\mathrm{O}$ arredondamento dos clastos é função de sua origem, com predomínio de formas esféricas arredondadas a

Tabela 2. Tabela de fácies da Formação Rincão dos Mouras na Sub-bacia Camaquã Oriental a norte do rio Camaquã.

\begin{tabular}{|c|c|c|}
\hline Código das fácies & Descrição & Interpretação \\
\hline $\begin{array}{l}\text { Cma } \\
\text { Conglomerados } \\
\text { maciços de matriz } \\
\text { argilosa }\end{array}$ & $\begin{array}{l}\text { Conglomerados oligomíticos sustentados pela matriz } \\
\text { (matrix-supported), formada por argila e fragmentos } \\
\text { detríticos de diversas frações granulométricas, de } \\
\text { ocorrência restrita a afloramentos isolados }\end{array}$ & $\begin{array}{l}\text { Depósitos de fluxo de } \\
\text { detritos, associados a } \\
\text { leques aluviais proximais }\end{array}$ \\
\hline
\end{tabular}

Conglomerados sustentados pelo arcabouço, maciços a

$\mathrm{Cm}$

Conglomerados

maciços a rudemente estratificados

$\mathrm{Ce}$

Conglomerados

com estratificação plano-paralela

rudemente estratificados, polimíticos, predominantemente com clastos arredondados da granulometria calhau a matacão ( $\phi_{\text {máx. }}=80 \mathrm{~cm}$ de leucogranito róseo grosso). A matriz é mal selecionada, formada por arenito arcoseano muito grosso a médio

Conglomerados polimíticos, organizados em camadas tabulares de até 1,5 m (em geral decimétricas), sustentados pelo arcabouço da granulometria seixo a matacão $\left(\phi_{\text {máx. }}=32 \mathrm{~cm}\right)$, cujos clastos são subangulosos a subarredondados. A matriz consiste de arenito grosso arcoseano, mal selecionado. Possuem intercalações decimétricas a métricas de arenitos conglomeráticos e arenitos com seixos e calhaus esparsos, originando pulsos granodecrescentes. Os clastos concentram-se em prismas de acumulação e nos planos da estratificação plano-paralela

Conglomerados polimíticos, organizados, com estratificação cruzada tabular, lentes arenosas intercaladas e feições

Ct

Conglomerados com estratificação cruzada tabular de médio e pequeno porte métricas de corte e preenchimento. Geralmente sustentados por matriz de arenito arcoseano mal selecionado, mas com ocorrência de lentes métricas sustentados pelo arcabouço,

com frequente imbricação de clastos, que possuem dimensões entre 2 e $12 \mathrm{~cm}$, com tamanho máximo de $18 \mathrm{~cm}$, e são subangulosos a arredondados
Depósitos de barras longitudinais de sistemas fluviais de rios entrelaçados de alta energia associados a leques aluviais ou depósitos de fluxo de detritos associados a leques aluviais proximais

Depósitos de correntes aquosas em barras fluviais de rios entrelaçados, ou de fluxos não canalizados, do tipo enchentes em lençol (sheet-flood sensu Blair \& McPherson 1994), associado a fácies de leques aluviais medianos a distais

Depósitos de preenchimento de canais de sistemas fluviais de rios entrelaçados de granulometria grossa associados a leques aluviais em ambiente de alta energia

Arenitos grossos a médios, excepcionalmente finos,

Ap Arenitos grossos a médios com estratificação plano-paralela

\section{$\mathrm{Aa}$}

Arenitos grossos a médios e arenitos conglomeráticos, com estratificação cruzada acanalada

At

Arenitos com estratificação cruzada tabular Af Arenitos com estruturas de fluidificação geralmente micáceos e arcoseanos, bem estratificados, dispostos em camadas normalmente tabulares de espessuras decimétricas, com estratificação plano-paralela e níveis centimétricos de seixos pequenos e grânulos na base das camadas que originam gradação normal

Arenitos grossos a médios arcoseanos e arenitos conglomeráticos, imaturos mineralógica e texturalmente, com estratificação cruzada acanalada de pequeno e médio porte, geralmente com concentração de clastos arredondados a subangulosos nos estratos frontais das estratificações

Arenitos grossos a médios, feldspáticos, com seixos esparsos, mal selecionados, com estratificação cruzada tabular de médio ângulo, em camadas normalmente lenticulares de pequeno e médio porte Arenitos maciços mal selecionados com estruturas reliquiares convolucionadas, amiúde com silte e/ou argila dispersos na matriz, e de camadas pelíticas interrompidas e dobradas
Depósitos de fluxo laminar superior em barras transversais ou linguoides de sistemas fluviais de rios entrelaçados
Depósitos de dunas subaquáticas de canais principais ou sistemas de canais fluviais entrelaçados de alta energia em regime de fluxo inferior

Depósitos de barras
transversais ou linguoides de rios
entrelaçados, invariavelmente
associados à fácies Aa
Perturbação de depósitos arenosos
por processos de perda de fluidos
e/ou fluidificação por sobrecarga


subangulosas nos granitoides e tabulares e angulosas em rochas metamórficas.

À medida que se caminha lateral e verticalmente na sucessão, passam a existir intercalações de conglomerados desorganizados a pouco organizados (fácies $\mathrm{Cm}$ ), rudemente estratificados, sustentados por arcabouço da granulometria calhau a matacão ( $\phi_{\text {máx. }}=74 \mathrm{~cm}$ leucogranito róseo grosso equigranular), conforme Figura 10A. A matriz desses conglomerados é mal selecionada, formada por arenito arcoseano grosso, com grãos de feldspato róseo, feldspato branco, quartzo, quartzitos e minerais pesados, e material fino. Os conglomerados exibem alguma seleção dos clastos (gradação normal) por estrato, o que gera a estratificação pouco desenvolvida observada. Por vezes, observou-se gradação inversa e imbricação de clastos.

Para o topo $\left(2^{\circ}\right.$ e $3^{\circ}$ megaciclos $)$, os conglomerados assumem organização (estratificados das fácies $\mathrm{Ce} e \mathrm{Ct}$ ), passam a polimíticos, de geometria tabular, sustentados por arcabouço constituído por clastos da granulometria seixo a matacão (Figuras 10B e 10C), com intercalações decimétricas a métricas de arenitos conglomeráticos e arenitos com seixos e calhaus esparsos das fácies Acg e Ct (Figuras 10D a $10 \mathrm{H}$ ). As duas últimas são as fácies dominantes nessa porção de topo. A matriz dos conglomerados é mal selecionada, formada por arenito arcoseano muito grosso a grosso com grânulos. Como estruturas sedimentares presentes destacam-se estratificação plano-paralela e cruzada dos tipos tabular e acanalado de pequeno e médio porte, com predomínio dessas últimas formas de leito. Os fragmentos concentram-se em prismas de acumulação e nos estratos frontais das estratificações, constituídos de leucogranitos róseos e quartzo de veio, principalmente.

As características dos conglomerados maciços sustentados por matriz argilosa (fácies $\mathrm{Cma}$ ), tais como desorganização interna, angulosidade dos clastos, granulometria até matacão, má seleção e imaturidade textural e mineralógica, indicam a atuação de mecanismos de transporte e acumulação de sedimentos de alta energia e alta viscosidade desses depósitos. A alta viscosidade do fluxo foi inferida da seleção muito pobre, na qual fragmentos de dimensões maiores flutuam em meio a matriz fina e da ausência de estratificação interna, de acordo com os estudos de Blissenbach (1954), Bull (1964), Hooke (1967), Bull (1972), Gloppen e Steel (1981), Nilsen (1982), Miall (1992), Blair e McPherson (1994), Miall (1996) e Blair (1999a, 1999b), entre outros. Conforme Hooke (1967) e Bull (1972), depósitos de fluxo de alta viscosidade encontram-se mais comumente junto ao ápice do leque, ou seja, em posição mais proximal. As características anteriormente apontadas sugerem a atuação de fluxos de detritos (debris-flow), de caráter proximal, com pouca matriz (sensu Schultz, 1984). Os conglomerados maciços suportados pelo arcabouço (fácies $\mathrm{Cm}$ ), excetuando-se a ausência de argila na matriz e o caráter sustentado por arcabouço dos depósitos, possuem as mesmas propriedades quanto à seleção, imaturidade textural e mineralógica, desorganização e arredondamento dos depósitos anteriores. Assim, representam depósitos de fluxo de detritos associados a leques aluviais em condições igualmente proximais em relação à área fonte. Desse modo, os depósitos são interpretados como as fácies proximais de sistemas de leques aluviais que se instalaram na bacia. Tal fato evidencia importante influência tectônica na sedimentação (bordas ativas) e assinalam um limite de sequências fundamental para a correlação do Grupo Santa Bárbara em termos de tectono-sequências.

A abundância de conglomerados estratificados sugere predomínio de fluxo desconfinado tipo enchentes em lençol de alta energia (sheet-flood) (Blair e McPherson, 1994; Blair, 1999a). Subordinadamente, aparecem depósitos de correntes fluviais, provavelmente gerados em canais rasos e largos e/ou de grande migração lateral. As superfícies de estratificação dos conglomerados Ce são realçadas por delgados níveis de arenitos grossos ou médios a conglomeráticos da fácies Acg $(30 \mathrm{~cm})$ contendo laminação plano-paralela ou estratificação cruzada tabular de pequeno porte, encerrando um ciclo granodecrescente ou, por vezes, marcando o início de um pulso granocrescente ascendente. Esse fato se deve a:

1. taxa de sedimentação rápida (episódica) situada nas porções médias de leques aluviais (Blair e McPherson 1994; Blair, 1999a, 1999b), imediatamente abaixo do ponto de intersecção do leque, onde o desconfinamento simultâneo de canais dos fluxos aquosos torrenciais associados à rápida deposição impediria o desenvolvimento mais significativo de superfícies de corte, refletindo em processo de enchentes em lençol;

2. tabularidade das camadas indicando condições de deposição a partir de fluxos subaquosos desconfinados, o que favorece uma sedimentação por depósitos de enchentes em lençol.

A falta de intercalações pelíticas mais pronunciadas e evidências de retrabalhamento por correntes sob regime de fluxo inferior (trativas) de alta energia (fácies Ct e Acg) sugerem a existência de condições deposicionais subaéreas. A estruturação interna das fácies Ce coaduna com as feições características de depósitos de fluxos aquosos de leques aluviais (depósitos de sheet flood e stream channel) — tal como discutido em Steel et al. (1977), Nilsen (1982), Blair e McPherson (1994) e Blair (1999b) —, a seguir enunciadas:

1. deposição relativamente próxima à área fonte;

2. maior organização dos depósitos com referência àqueles mais proximais, embora preservando a imaturidade textural e mineralógica dos depósitos;

3. depósitos canalizados e com estratificação cruzada acanalada e tabulares de pequeno e médio portes;

4. granodecrescência ascendente; e

5. imbricação dos clastos. 

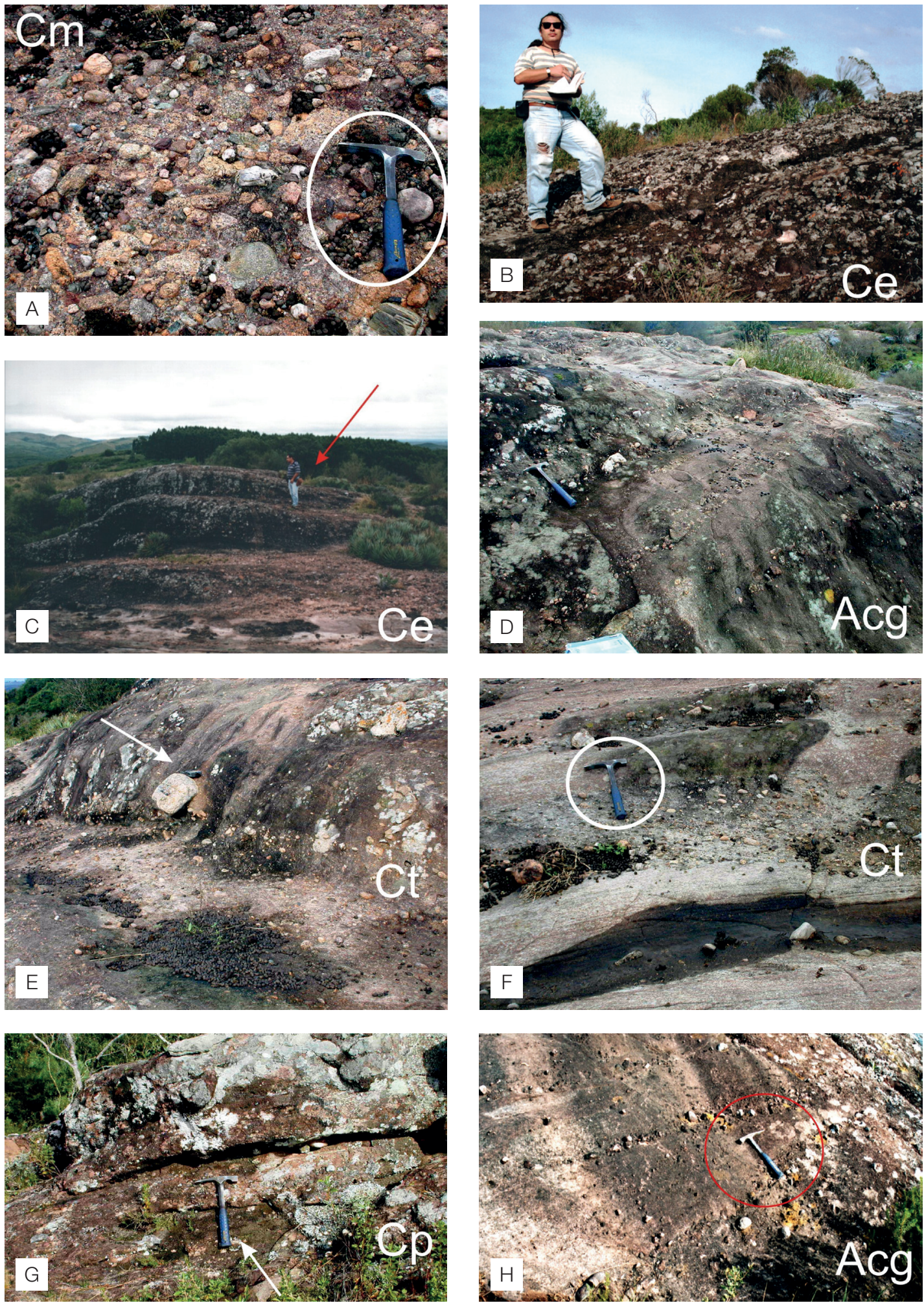

Figura 10. Fácies de conglomerados e arenitos de leques aluviais da Formação Rincão dos Mouras na região homônima. (A) conglomerados maciços $\mathrm{Cm}$; (B) conglomerados estratificados $\mathrm{Ce}$; (C) conglomerados estratificados Ce; (D) conglomerados lenticulares e arenitos conglomeráticos Acg; (E) conglomerados com estratificação cruzada tabular $C t$ e arenitos conglomeráticos Acg, bússola de escala (ver seta); (F) conglomerados com estratificação cruzada tabular $C t$, (G) conglomerados com estratificação plano-paralela $C p ;(H)$ arenitos conglomeráticos com estratificação cruzada acanalada Acg. Círculos e setas indicam escalas utilizadas. 
Associação de fácies de arenitos e arenitos conglomeráticos

Essa associação de fácies possui passagem gradacional lateral e verticalmente com a associação de conglomerados e apresenta ocorrência monótona de arenitos com intercalações conglomeráticas. Assim, destacam-se as seguintes fácies:

1. conglomerados estratificados (fácies Ce);

2. conglomerados com estratificação cruzada tabular de médio e pequeno porte (fácies $\mathrm{Ct}$ );

3. arenitos conglomeráticos com estratificação cruzada acanalada de pequeno e médio porte (fácies Acg);

4. arenitos maciços (fácies Am);

5. arenitos grossos a médios com estratificação cruzada acanalada de médio e pequeno porte (fácies Aa);

6. arenitos médios a finos com estratificação plano-paralela (fácies Ap);

7. arenitos com estratificação cruzada tabular (fácies At);

8. arenitos com estruturas de fluidificação (fácies Af).

Os conglomerados estratificados (fácies Ce) são polimíticos, organizados (estratificados), de geometria predominantemente lenticular, sustentados por arcabouço constituído de clastos em geral arredondados e de esfericidade média a alta, granulometria seixo pequeno a matacão $\left(\phi_{\text {máx }}=49 \mathrm{~cm}\right.$, pegmatito). A estratificação plano-paralela da rocha é denotada pela gradação normal e orientação dos clastos, sendo melhor observada nos termos discoides e alongados. É composta por camadas de espessura variada, desde métricas (1 a $3 \mathrm{~m})$ a decimétricas $(10 \mathrm{a} 15 \mathrm{~cm})$.

Os conglomerados da fácies $\mathrm{Ct}$ são polimíticos, organizados, com estratificação cruzada tabular de médio e pequeno porte, lentes arenosas intercaladas e feições métricas de corte e preenchimento. Geralmente mostram-se sustentados por matriz de arenito arcoseano mal selecionado (arcabouço $<50 \%$ ), mas com ocorrência de lentes métricas de conglomerados sustentados por arcabouço, com frequente imbricação de clastos. Esses possuem dimensões entre 2 e $12 \mathrm{~cm}$, com tamanho máximo de $18 \mathrm{~cm}$, e são subangulosos a arredondados.

Os arenitos grossos a médios da fácies Acg são conglomeráticos, organizados (estratificados), com seixos (predominantemente) e calhaus (esporadicamente) e apresentam coloração róseo-avermelhada a creme. A matriz é constituída por arenito grosso a médio, por vezes com grânulos, mal selecionada, com grãos angulosos a subarredondados. Esses arenitos conglomeráticos apresentam abundantes estratos com estratificação cruzada acanalada de pequeno e médio portes, com clastos dispondo-se nos estratos frontais das cruzadas (foresets). Lateralmente, passam para arenitos médios maciços (fácies Am) a bem estratificados (fácies Ap), com seixos esparsos e estratificação plano-paralela conspícua. Para o topo, aumentam a espessura das camadas e a granulometria dos clastos, além de apresentarem maior abundância de fragmentos de composição granítica.
Entretanto, a principal fácies desses depósitos são os arenitos grossos a médios com estratificação cruzada acanalada de médio e pequeno porte (fácies Aa), com clastos dispondo-se nos estratos frontais, realçando-as. Ocorrem concentrações de clastos na base das camadas e em prismas de acumulação. Os pacotes são decimétricos a métri$\cos (70 \mathrm{~cm}$ a $1,5 \mathrm{~m}$ de espessura).

A fácies de arenitos com estruturas de fluidificação (Af), de ocorrência restrita, compõe-se de arenitos muito mal selecionados, maciços ou com estruturas reliquiares convolucionadas, frequentemente com proporções variáveis de silte e/ou argila dispersos na matriz, além de micas e raros grânulos. Devido à presença ocasional de laminação contorcida, preservada em meio à massa mal selecionada, e de camadas pelíticas interrompidas e complexamente dobradas, interpreta-se essa fácies provavelmente como resultado de perturbação de depósitos arenosos e siltosos por processos de perda de fluidos e/ou fluidificação por sobrecarga, apesar da sismicidade identificada na bacia.

As características supracitadas permitem, de acordo com os trabalhos sobre sistemas fluviais de Rust (1972), Cant e Walker (1978), Blair e McPherson (1994), Miall (1977, 1981, 1996), Blair (1999a, 1999b), Blair e McPherson (2009), Miall e Jones (2003) e McLaurin e Steel (2007), considerar esses depósitos como originados por rios entrelaçados arenosos distais (distal braided), com processos de enchentes em lençol, em razão da presença de fluxo desconfinado, interpretação corroborada pela ausência tanto de grandes canais quanto de planícies de inundação.

\section{Análise de Paleocorrentes}

Nos arenitos e conglomerados fluviais da Formação Rincão dos Mouras foi obtido o maior número de medidas de paleocorrentes de todo o Grupo Santa Bárbara em um só tipo de depósito, sendo obtidos mais de 600 dados de paleocorrentes, principalmente em estratos frontais das estratificações cruzadas acanaladas e tabulares presentes nesses depósitos (Figuras 2).

As paleocorrentes medidas inicialmente possuem padrão de dispersão para E, notadamente na base da unidade $1^{\circ}$ megaciclo, o que sugere fonte dos sedimentos situada a $\mathrm{W}$ e indica que $\mathrm{o}$ alto de embasamento hoje observado provavelmente não se encontrava à época de deposição desse pacote, havendo continuidade dos depósitos aluviais. Outra conclusão pertinente é a de que as duas outras ocorrências da Formação Rincão dos Mouras (Figura 2), a sul e a norte da área principal de exposição, representem porções basais da unidade.

No $2^{\circ}$ megaciclo foi coletado o maior número de medidas. A análise de paleocorrentes indica mudança do padrão com transporte preferencial para NW e W (Figuras 2 e 17), sugerindo que a área fonte principal de contribuição de sedimentos situava-se a leste, tal como previamente levantado por Lavina et al. (1985), Caravaca et al. (1995) e Caravaca (1998). A leste 
encontram-se rochas do embasamento metamórfico (Complexo Porongos), rochas granitoides do Granito Encruzilhada do Sul, Granito Campina e Suíte Cordilheira, todas com clastos representados na análise de proveniência realizada (ver item seguinte).

No entanto, a porção de topo ( $3^{\circ}$ megaciclo $)$ dos depósitos fluviais exibe padrão de dispersão predominante para SE (Figura 17), sugerindo uma modificação no embasamento da bacia, com a ascensão de altos a NNW, provavelmente o Complexo Porongos.

A análise de paleocorrentes implementada na Formação Rincão dos Mouras sugere controle tectônico importante durante o preenchimento da unidade, com mudanças de fontes de detritos para a bacia e soerguimento de altos então adjacentes.

Vale ressaltar que, em outra ocorrência do Grupo Santa Bárbara na Sub-bacia Camaquã Oriental, na região do Arroio Boici, a sul do rio Camaquã, esse padrão de inversão da dispersão dos sedimentos também ocorre, ainda que caracterizado por um número menor de medidas. Na região constatou-se que os depósitos aluviais proximais de topo do Grupo Santa Bárbara apresentam padrão de paleocorrentes para S e SE inicialmente e, na planície aluvial, para SW ao longo da calha da bacia (Fambrini et al., 1992; Sayeg, 1993), coerente com a análise de proveniência. Ambas as análises mostram derivação de altos do embasamento situados a NNW (Complexo Porongos).

\section{ANÁLISE DE PROVENIÊNCIA}

\section{Proveniência da Formação Passo da Capela}

As brechas lenticulares basais apresentam composição dos clastos do arcabouço derivada das rochas do embasamento adjacente (Figura 10). Os fragmentos, junto à base, são de quartzo, leucogranito cinza com muscovita, leucogranitos róseos grossos, filitos, xistosa verdes, metarriolitos, milonitos e granitos finos, e, à medida que progredimos para o topo, aumenta sobremaneira a participação de quartzo de veio e de milonitos diversos.

Os conglomerados da Associação de Fácies 2 apresentam composição dos clastos do arcabouço derivada de unidades da própria sub-bacia (arenitos, principalmente), indicando a atuação de processos de autofagia bem como de rochas do embasamento (quartzitos, xistos, metarriolitos etc.), como pode ser verificado nas Figuras 11 e 12. As análises de proveniência mostram-se coerentes com as de paleocorrentes, indicando dispersão dos sedimentos a partir de SSW, onde se destacam litotipos oriundos do Complexo Porongos, tais como quartzitos, metarriolitos e milonitos em geral. A presença de clastos de granitos (e.g. Passo da Capela; Figura 12A) pode ser atribuída a núcleos graníticos preservados da intensa milonitização que afetou esse complexo.

Na região a leste de Capané, por exemplo, a análise de proveniência dos conglomerados mostra derivação principalmente do
Sienito Piquiri, mas também de rochas do Granito Encruzilhada do Sul (Figuras 3 e 13). É importante salientar que a proveniência reflete contribuição detrítica do embasamento adjacente ao depósito conglomerático (e.g. clastos do Sienito Piquiri), indicando que movimentações laterais do substrato da bacia não ocorreram ou, caso aconteceram, não foram importantes na deposição do Grupo Santa Bárbara.

Amostras de arenitos finos da Formação Passo da Capela foram descritas petrograficamente. Em geral, os arenitos são arcóseos (fácies de arenitos finos, maciços ou laminados; Figura 14A) e litoarenitos feldspáticos (fácies de arenitos finos com clastos), de acordo com a classificação de Folk (1968). O arcabouço é composto por quartzo monocristalino do tipo ígneo com abundantes vacúolos e micrólitos, quartzo policristalino dos tipos metamórfico recristalizado e cisalhado (sheared-quartz) (Figuras 14A a 14C), muscovita fresca e cloritizada, plagioclásio fresco e alterado, biotitas ferruginizadas e fragmentos líticos, como xistos (Figura 14B), metapelitos de baixo grau e quartzitos. A cimentação é dominantemente carbonática espática e do tipo molde (Figura 14D), embora ocorra cimento de óxido de Fe pelicular. Também foi observada pseudomatriz dada por filossilicatos e rochas (meta)pelíticas esmagadas.

\section{Proveniência da Formação Rincão dos Mouras}

Os conglomerados aluviais dessa formação possuem proveniência diversificada atestada pelas análises implementadas. Conforme a proposta de distribuição em megaciclos constante na Figura 9, a análise de proveniência demonstra variação de áreas fonte durante o preenchimento da Formação Rincão dos Mouras.

No $1^{\circ}$ megaciclo (Figuras $15 \mathrm{~A}$ e $15 \mathrm{~B}$ ) ocorrem clastos de milonito-granito, quartzito, quartzo de veio,

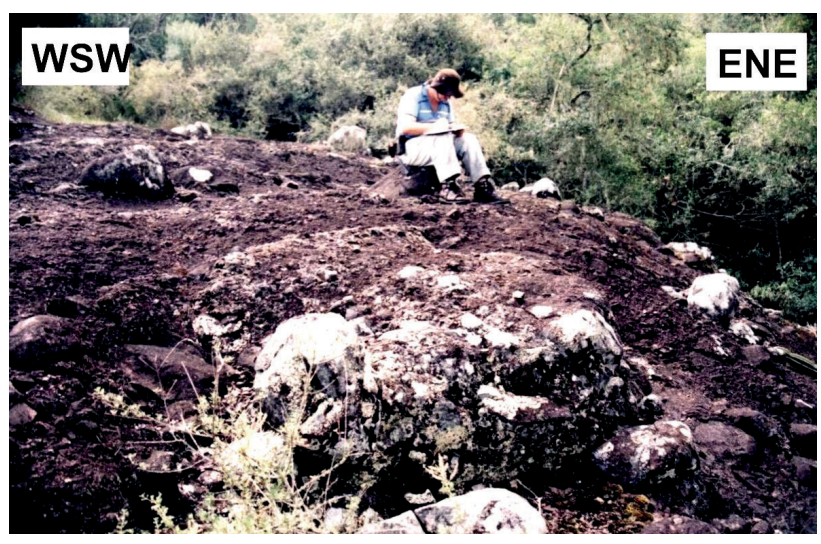

Figura 11. Matacões muito grossos de arenitos em conglomerados maciços de leques subaquosos da Associação de Fácies 2 da Formação Passo da Capela no Vale do Piquiri. Entre eles encontra-se um, onde o geólogo de escala se encontra, que atinge 3,2 $\mathrm{m}$ de tamanho. 


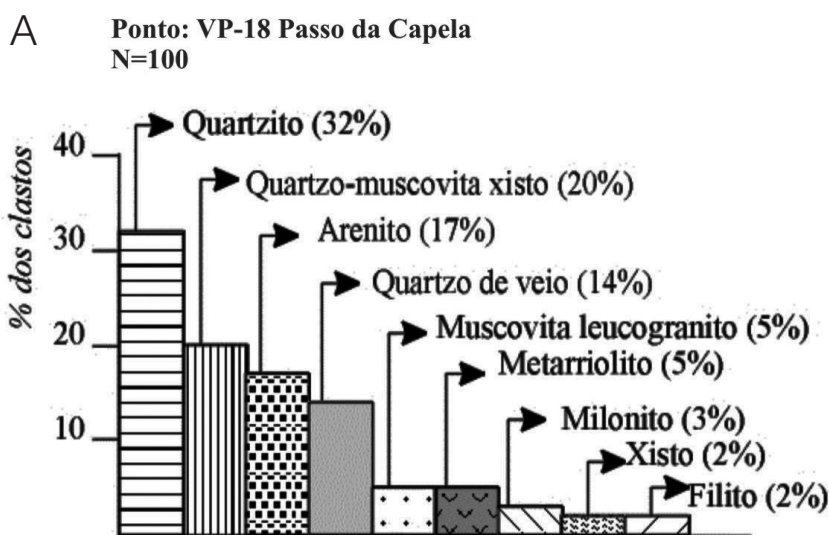

Composição dos clastos

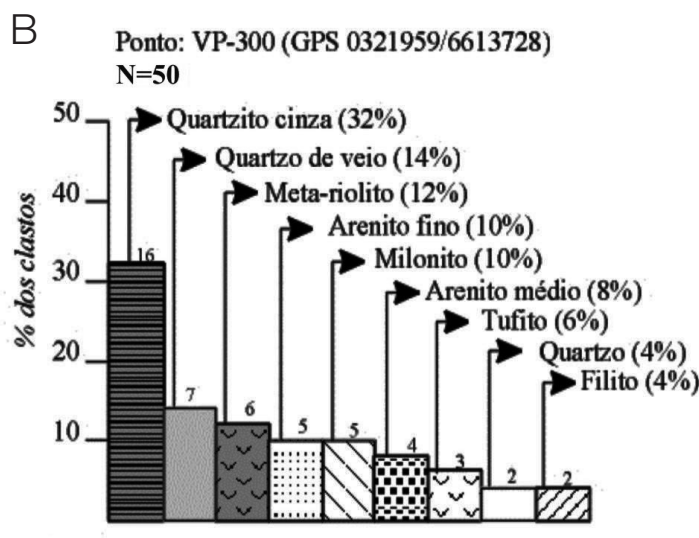

Composição dos clastos

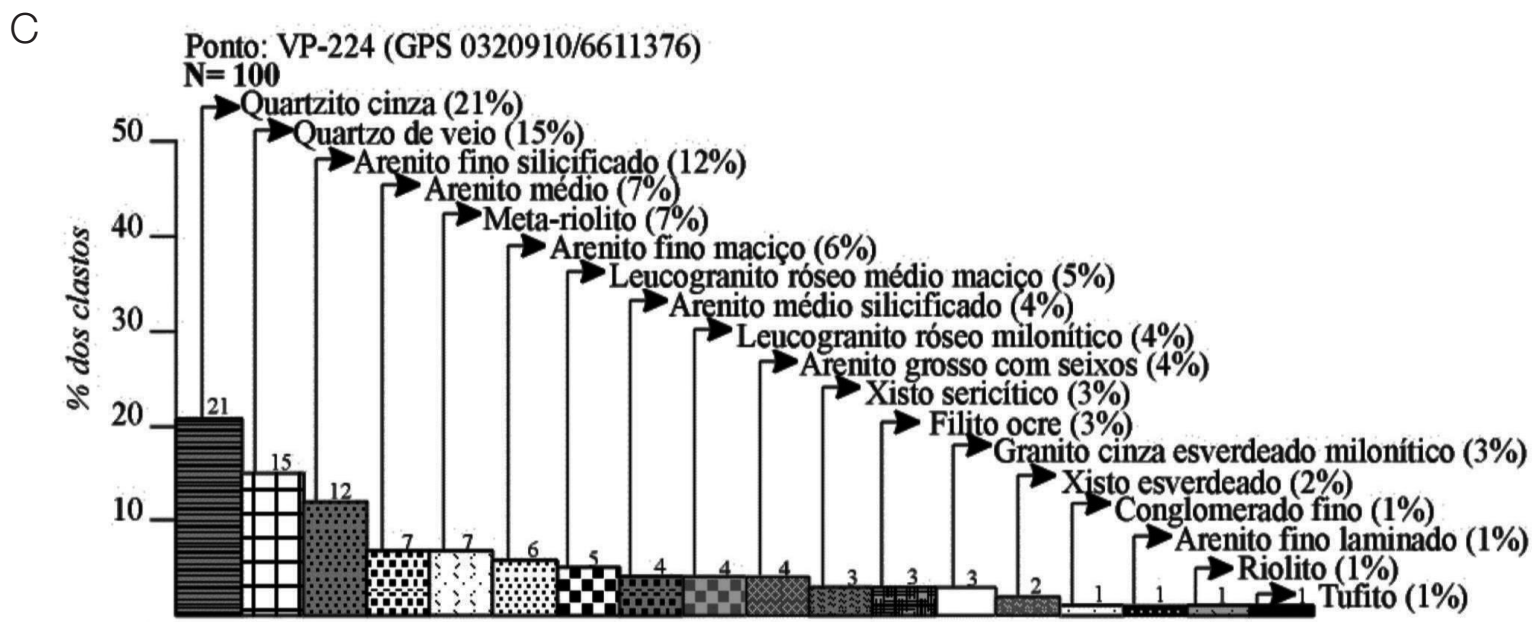

Composição dos clastos

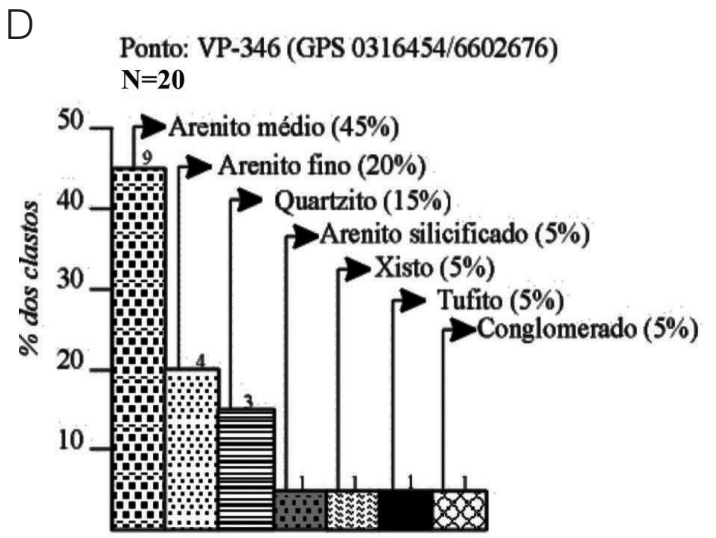

Composição dos clastos

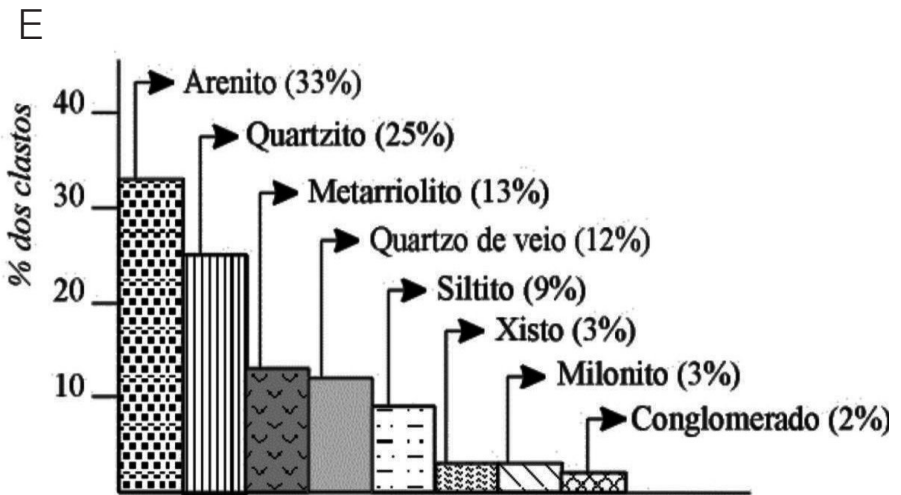

Composição dos clastos

VP: Vale do Piquiri; N: número de medidas.

Figura 12. Diagramas de barras com a proveniência de conglomerados de leque subaquoso interno a intermediário da Formação Passo da Capela na Sub-bacia Camaquã Oriental. 


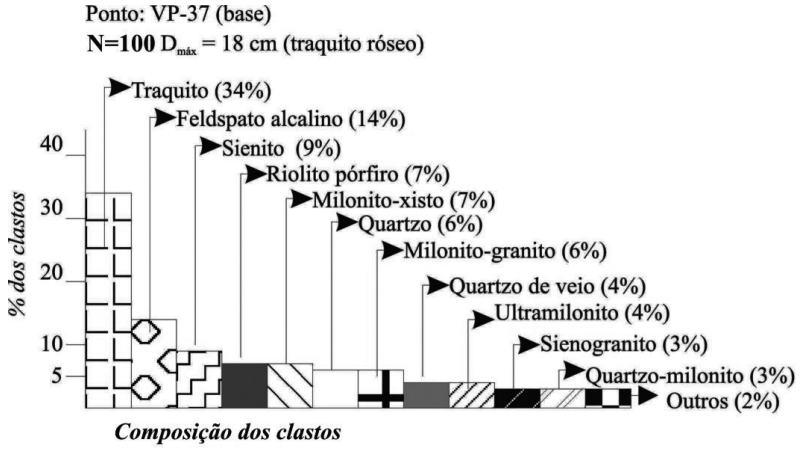

VP: Vale do Piquiri; N: número de medidas.

Figura 13. Diagramas de barras com a proveniência de conglomerados de leques subaquosos proximais a intermediários da Formação Passo da Capela na Sub-bacia Camaquã Oriental junto ao Sienito Piquiri.
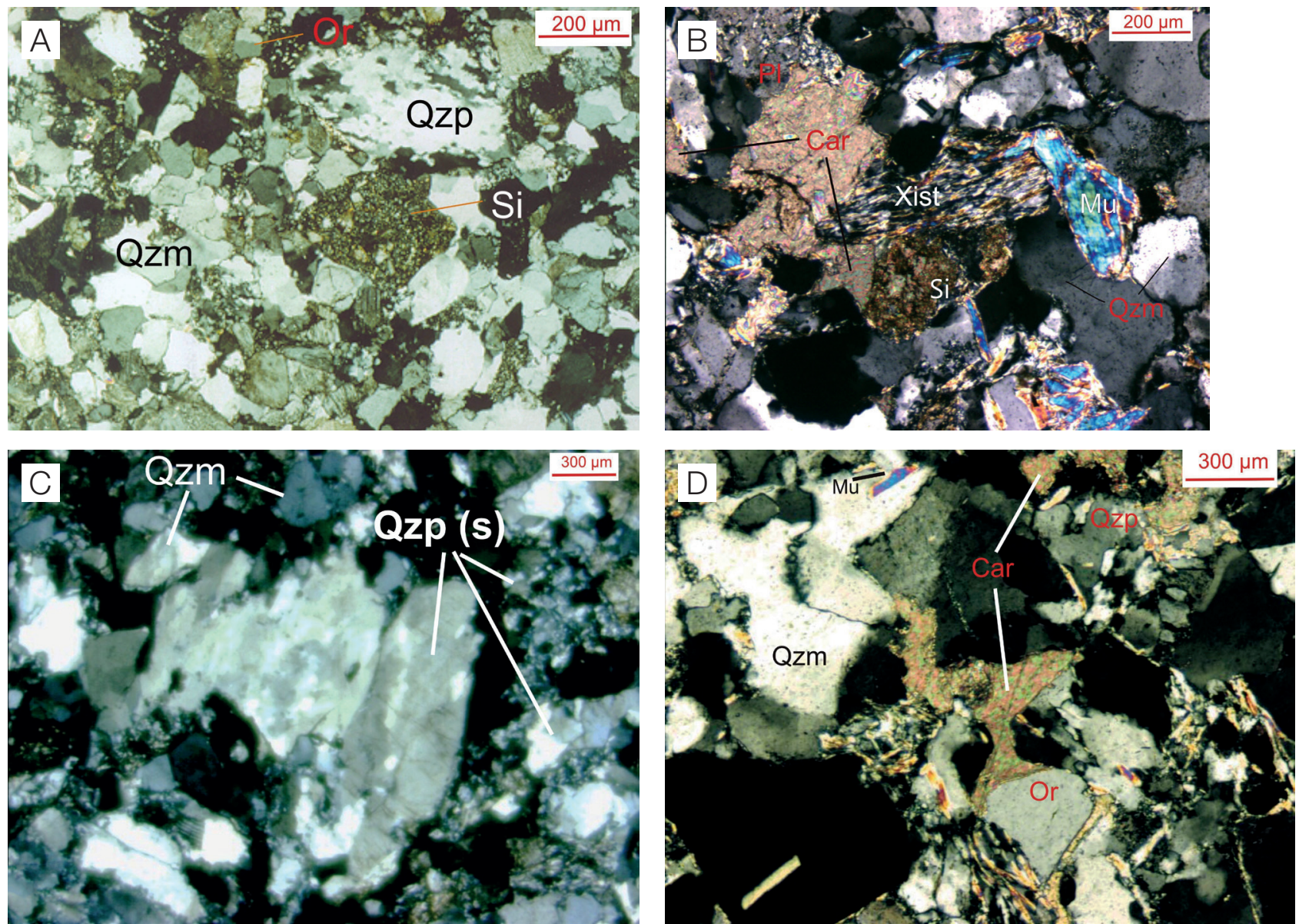

Qzp: quartzo policristalino tipo cisalhado; Qzm: quartzo monocristalino; Si: siltito; PI: plagioclásio semialterado; Car: cimentação carbonática do tipo espática; Xist: quartzo xistos; Mu: muscovita; Or: ortoclásio subarredondado.

Figura 14. Fotomicrografias de arenitos finos da sucessão de turbiditos lacustres da Formação Passo da Capela. (A) visão geral do arcabouço de arcóseos de matriz fina ausente. Aumento de 5x com luz polarizada; (B) aspecto do arcabouço dos arenitos com clastos que exibe grãos angulosos a subarredondados de quartzo dos tipos monocristalino e quartzo policristalino cisalhado, siltitos; quartzo xistos, plagioclásio semialterado e muscovita. Destaque para a cimentação carbonática do tipo espática. Aumento de 20x, luz polarizada; (C) detalhe de fragmentos de quartzo policristalino tipo cisalhado (sheared-quartz). Aumento de 10x com luz polarizada; (D) aspecto do arcabouço dos turbiditos que exibe grãos angulosos de quartzo monocristalino, quartzo policristalino tipo cisalhado e ortoclásio subarredondado, além de pequenos grãos de muscovita. Destaque para a cimentação carbonática do tipo espática. Aumento de 20x, luz polarizada. 
A

Ponto: VP-145 (GPS 0316476/6605434)

$\mathbf{N}=\mathbf{5 0}$

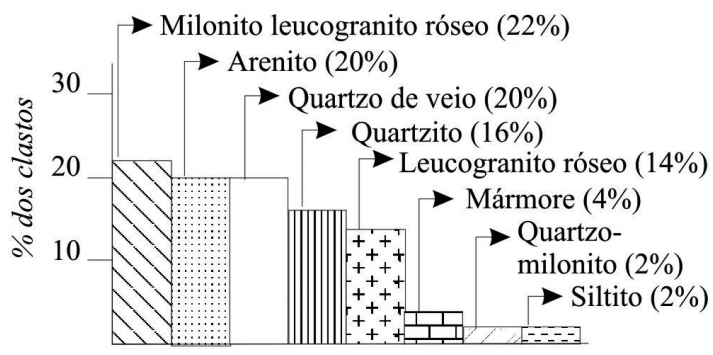

Composição dos clastos

C Ponto: VP-57 (GPS 313882/6617825) $\mathbf{N}=\mathbf{1 0 0}$

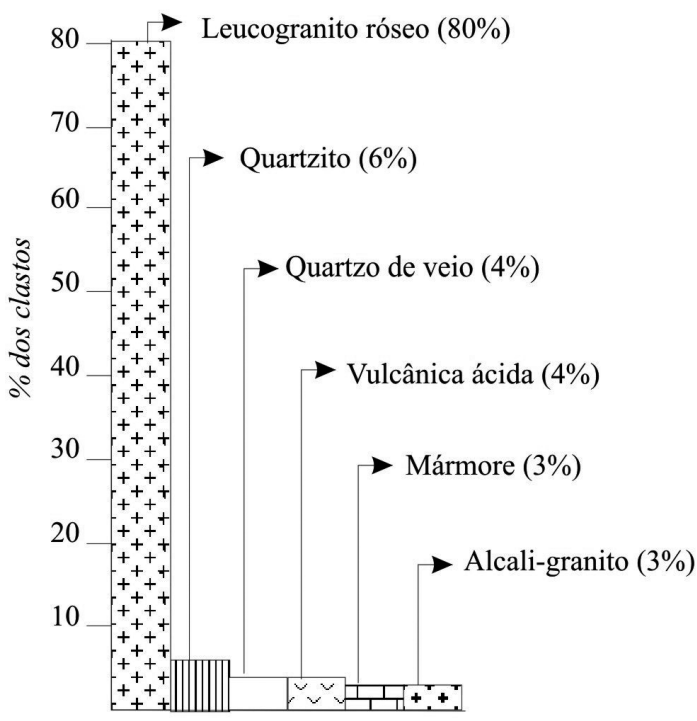

Composição dos clastos

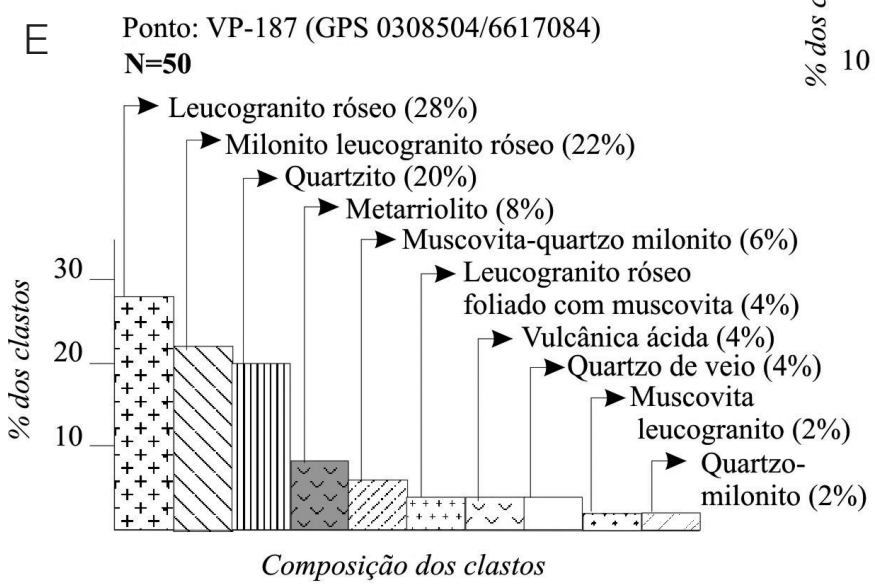

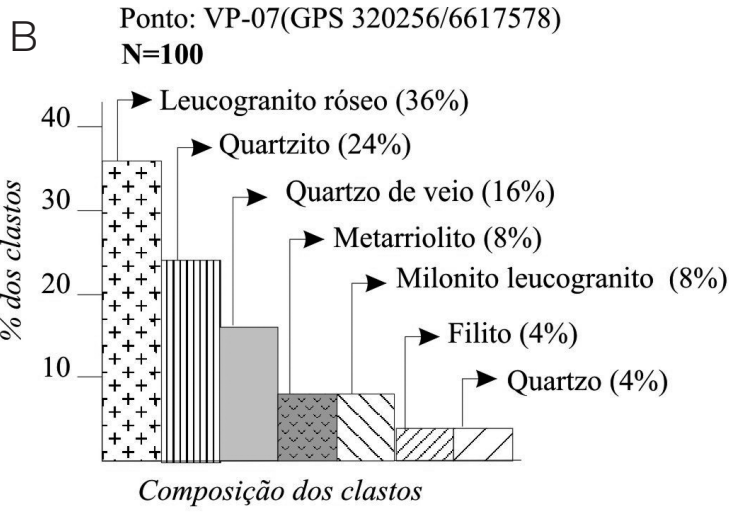

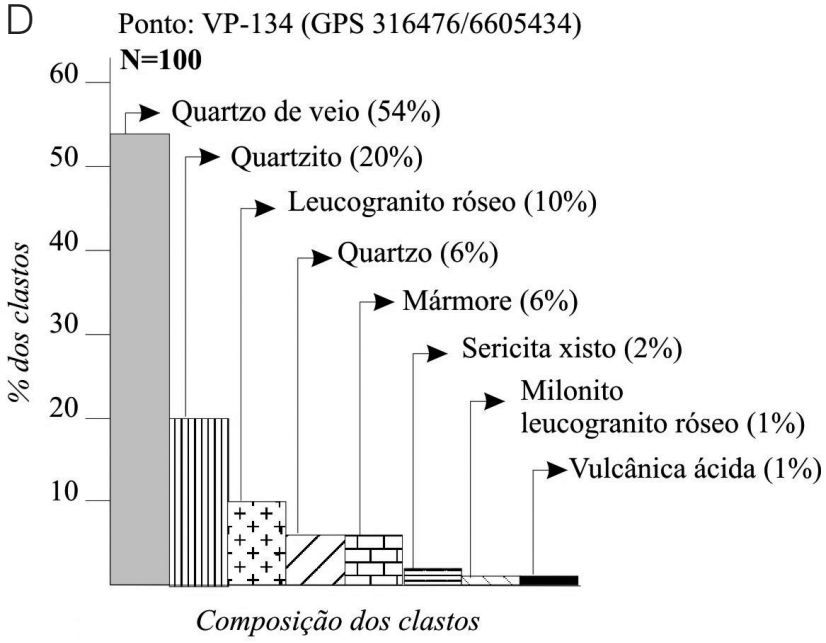

F

Ponto: VP-183 (GPS 0307050/6614646)

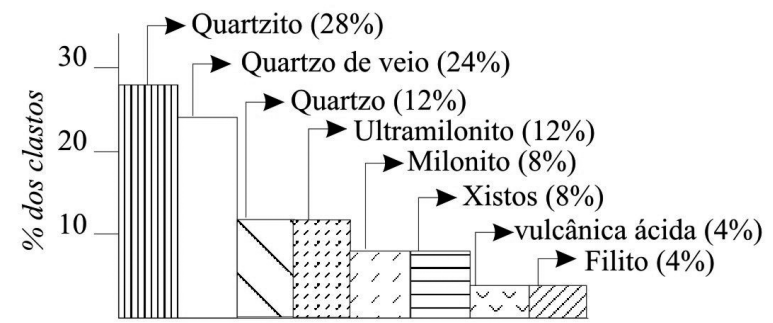

Composição dos clastos

P. Vale do Piquiri; N: número de medidas.

Figura 15. Diagramas de barras com a proveniência de conglomerados e arenitos aluviais da Formação Rincão dos Mouras na Sub-bacia Camaquã Oriental. (A) e (B) proveniência do $1^{\circ}$ megaciclo; (C a F) proveniência do $2^{\circ}$ megaciclo. 
quartzo-milonito, metarriolito, quartzo, arenito e siltito laminado, mármore, quartzo-milonito e leucogranito róseo. A proveniência sugere a denudação de altos de embasamento formados por rochas metamórficas, correlacionadas ao Complexo Porongos (e.g. metarriolito), granitoides isótropos, possivelmente núcleos graníticos preservados da milonitização que afetou esse complexo, e da própria bacia (e.g. arenito laminado), provavelmente dos turbiditos da Formação Passo da Capela, coerente com os dados de paleocorrentes adiante discutidos.

No $2^{\circ}$ megaciclo destacam-se clastos de leucogranito róseo (fácies porfirítica característica) e muscovita leucogranito (predominantes), correlacionáveis ao Granito Encruzilhada do Sul. Aparecem também clastos de milonito-granito, quartzito, vulcânica ácida, quartzo de veio, quartzo, quartzo-milonito, metarriolito, muscovita-quartzo xisto, mármore, filito e poucos xistos muito micáceos oriundos do Complexo Porongos. Turmalina granitos aparecem em pequenas proporções. Fragmentos de sienito e traquito, seguramente correlacionáveis ao Sienito Piquiri, podem ser verificados em pequena proporção, assim como arenitos e intraclastos argilosos (Figuras 15C a $15 \mathrm{~F}$ e 16). A análise de proveniência desse megaciclo indica que áreas a leste estavam sendo soerguidas e erodidas, como o Granito Encruzilhada do Sul e o próprio Complexo Porongos, conforme previamente notado por Caravaca et al. (1995) e Caravaca (1998). No entanto, a análise aqui efetuada difere desses autores pela praticamente ausência de clastos de turmalina granitos, os mais abundantes encontrados pelos citados autores. Por outro lado, a presença de litologias derivadas inequivocamente do Granito Encruzilhada (leucogranito róseo porfirítico) e da Suíte Cordilheira (muscovita granito), aliada às análises de paleocorrentes efetuadas, indica que a região a leste da Sub-bacia Camaquã Oriental comportou-se como alto de embasamento fornecedor de sedimentos para a bacia (Figura 17), conclusão semelhante à de Caravaca (1998).

A proveniência realizada nos arenitos conglomeráticos do $3^{\circ}$ megaciclo (Figuras 16E e 17), apesar das poucas análises, distingue-se apenas pelo desaparecimento gradual de clastos de muscovita granito e de turmalina granito para o topo, e do maior arredondamento dos clastos, compatível com o paleoambiente de rios entrelaçados que dominam essa porção, o que decorre de uma mudança no substrato da bacia, com o soerguimento de altos a NW, como se denota das paleocorrentes medidas (Figura 2).

Petrograficamente, na Formação Rincão dos Mouras destacam-se abundantes grãos de quartzo policristalino dos tipos metamórfico recristalizado e cisalhado, mas também do tipo monocristalino plutônico. Plagioclásio supera microclínio em termos de feldspato, mas ortoclásio também ocorre.

\section{DISCUSSÃO}

O empilhamento estratigráfico da Sub-bacia Camaquã Oriental permite a caracterização de ciclos progradacionais-retrogradacionais, interpretados como resultado de variações relativas do nível de base, possivelmente relacionadas em alguma medida a mudanças no equilíbrio entre subsidência e aporte sedimentar, ambos relacionados à evolução tectônica da Bacia do Camaquã. A influência da tectônica se dá principalmente por meio de mecanismos de geração de espaço de acomodação para o preenchimento sedimentar condicionado pela subsidência tectônica do substrato da bacia e a deposição de sedimentos mais finos (Blair e Bilodeau, 1988). As taxas de subsidência elevadas implicam no grau de erosão das áreas emersas que contribuirão com detritos para o preenchimento da bacia, atestadas pelo grande número de fácies de turbiditos e, no contato com o embasamento, de brechas proximais. Por fim, as taxas de aporte sedimentar estão sujeitas à relação entre os dois fatores anteriores e às condições climáticas atuantes durante a sedimentação e nas áreas fonte. Esse quadro em conjunto possibilita a elaboração de um modelo paleogeográfico para a região.

A deposição do Grupo Santa Bárbara foi controlada pelas estruturas antigas do embasamento, que geraram um amplo sistema de hemi-grábens com sistema de falhas mestras instaladas na borda leste da bacia. Nela, durante a fase de preenchimento inicial da sub-bacia, ocorrem depósitos deltaico-lacustres de leque subaquoso da Formação Passo da Capela. Nessa fase de evolução paleogeográfica do Grupo Santa Bárbara predominaram sistemas lacustres de águas rasas e pouco mais profundas, cujo depocentro se situava a norte, compreendendo lago com variações do nível de base. Esse corpo lacustre é representado pelos depósitos de leques subaquosos e turbiditos. A presença de depósitos de leques subaquosos e turbiditos a sul indica a presença de cânions ou canais das porções proximais a medianas de leques subaquosos que serviram de transporte de fluxos sedimentares densos, os quais foram movimentados para as porções mais distais do leque por correntes de turbidez de baixa densidade em um sistema deltaico-lacustre.

Os depósitos de leque subaquoso (delta-lacustre) correspondem ao primeiro conjunto de eventos que propiciaram aporte sedimentar depositados na região, e indicam que o início da sedimentação encontrava-se registrado na porção leste-sul do Vale do Piquiri. Esses depósitos da Associação 1 compreendem delgadas ocorrências (50 $\mathrm{m}$ de espessura máxima) de conglomerados e arenitos, que passam rapidamente para ritmitos. As frações mais grossas e imaturas correspondem aos depósitos proximais provenientes das áreas fonte, após o soerguimento dessas em contrapartida ao abatimento causado pelo rifteamento, originando os deltas-lacustres com sedimentos mais finos. 


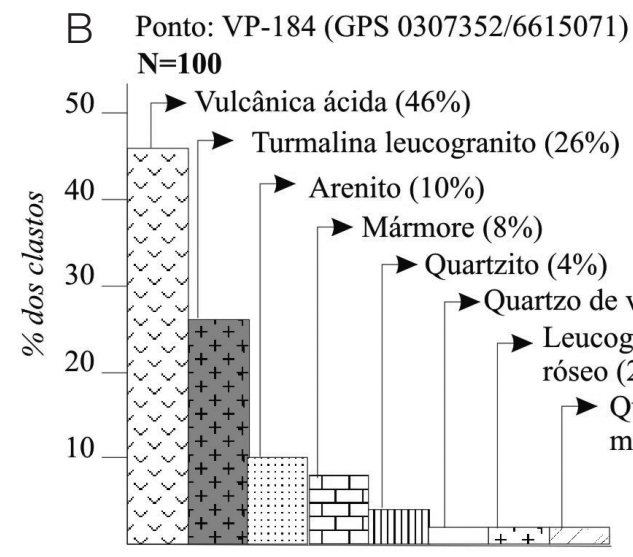

Composição dos clastos

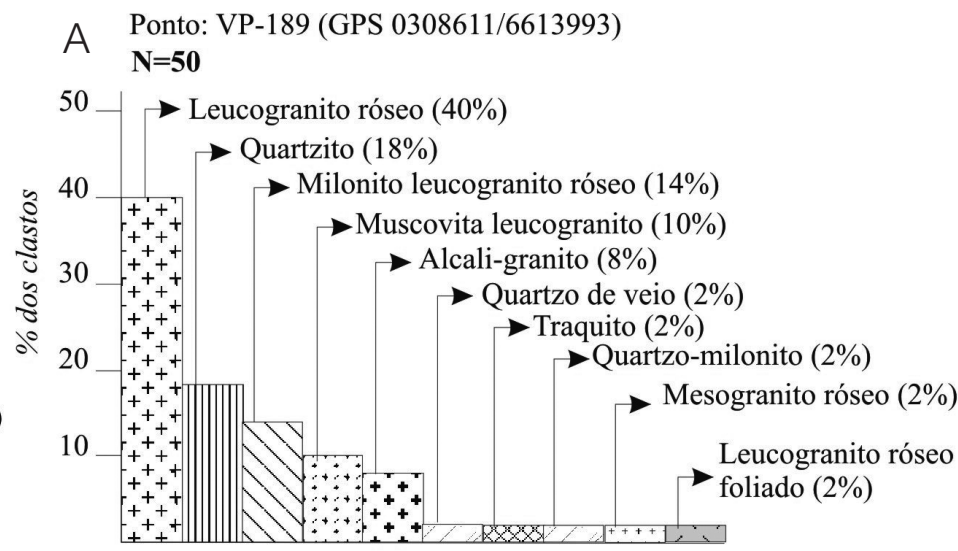

Composição dos clastos

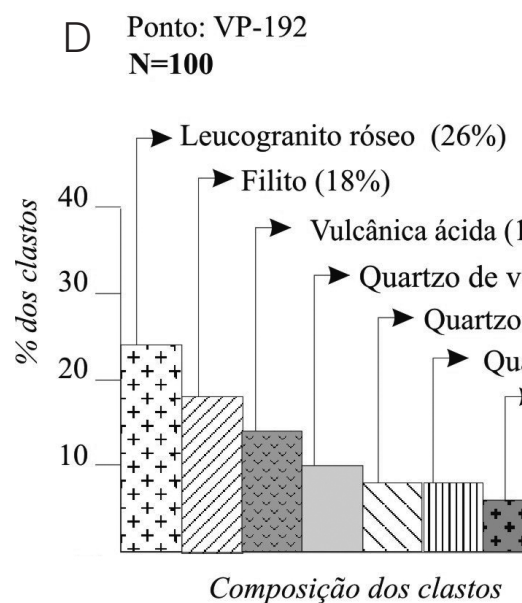

VP: Vale do Piquiri; N: número de medidas.

Figura 16. Diagramas de barras com a proveniência de conglomerados e arenitos aluviais da Formação Rincão dos Mouras na Sub-bacia Camaquã Oriental. (A a D) proveniência do $2^{\circ}$ megaciclo; (E) proveniência do $3^{\circ}$ megaciclo. 
Os depósitos de leque subaquoso ocorrem com maior importância conforme se aproxima do sul da bacia. Esses depósitos foram associados aos canais de leque proximal a intermediário. A distinção precisa entre eles não pode ser feita, pois faltaram observações de contato do cânion com o embasamento, uma vez que um cânion é definido por erodir um substrato composto por rochas ígneas, metamórficas ou mesmo sedimentares mais antigas (Nilsen, 1985). Nos domínios dos cânions e canais das porções proximais de leques subaquosos, os mecanismos deposicionais atuantes são predominantemente controlados pelos efeitos que a concentração de clastos causa em seu próprio suporte. A associação de fácies de conglomerados e arenitos de leque subaquoso da Associação 2 indica a participação de fluxos sedimentares de alta densidade. O fluxo de detritos (debris flow) é tido como o principal responsável pelos depósitos dessa associação faciológica, mas também correntes de turbidez de alta densidade. Por intermédio do fluxo de detritos, partículas de grandes dimensões podem ser transportadas em suspensão em razão da concentração de uma matriz representada pela mistura intersticial de água e sedimentos finos (fluxo hiperconcentrado).

Os turbiditos lacustres (porção distal da Formação Passo da Capela) da Associação 3 representam, assim como os seus equivalentes da porção inferior, depósitos de sistemas de leques subaquosos deltaico-lacustres. As associações de fácies presentes em ambas as sequências são análogas. No entanto, os turbiditos da Associação 3 aparentemente depositaram-se em um momento em que a bacia começava a passar de condições típicas de águas profundas para águas mais rasas, registradas nas abundantes estruturas onduladas (climbing ripples de crista reta). Esses depósitos mantêm a característica de grande continuidade lateral, inerente aos mecanismos de fluxos turbulentos não confinados.

As paleocorrentes coletadas nos depósitos da Formação Passo da Capela no Vale do Piquiri revelaram uma direção de paleofluxo consistente para NNE, ou seja, longitudinal à orientação geral da Sub-bacia Camaquã Oriental no Vale do Piquiri (Figura 2). Esse padrão longitudinal de paleocorrentes em relação às bordas de uma bacia é típico de depósitos de turbiditos de leques subaquosos e coerente com a

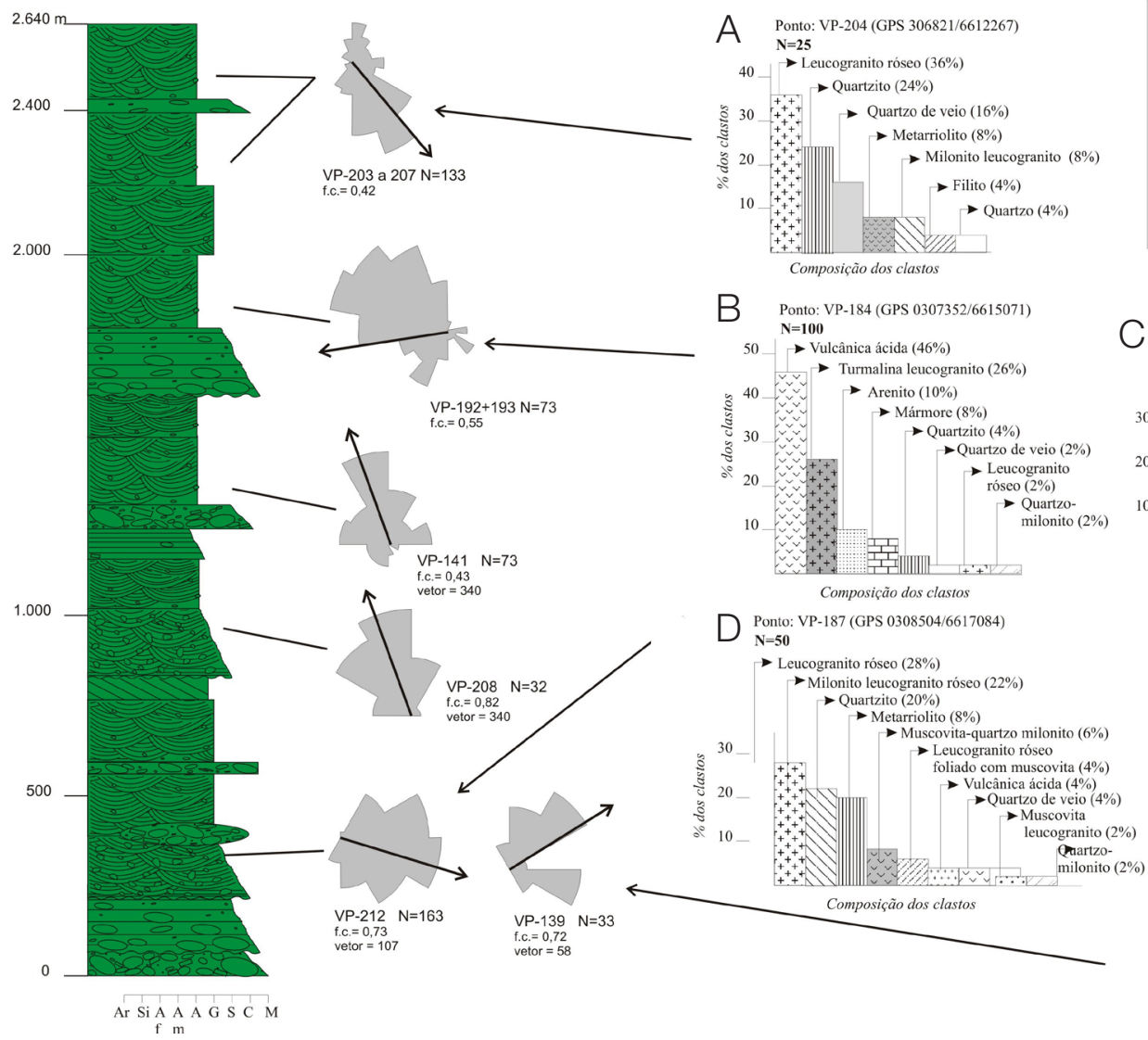

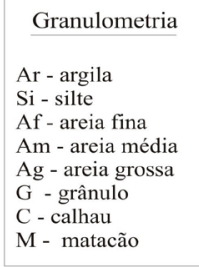

$\mathrm{C}_{\mathrm{N}=\mathbf{5 0}}^{\text {Ponto: }}$ VP-190 (GPS 0308813/6613696) $\mathbf{N}=\mathbf{5 0}$

Milonito leucogranito róseo $(28 \%$ Leucogranito róseo $(22 \%)$ Quartzito $(22 \%)$ Muscovita-quartzo xisto $(10 \%$ $\rightarrow$ Alcali-granito $(8 \%)$

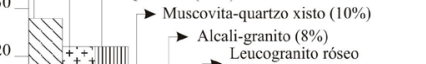
\begin{tabular}{rl|l}
+++ \\
+++ \\
+++ \\
++
\end{tabular}

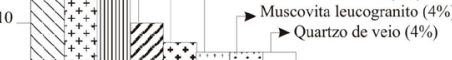
Composição dos clastos

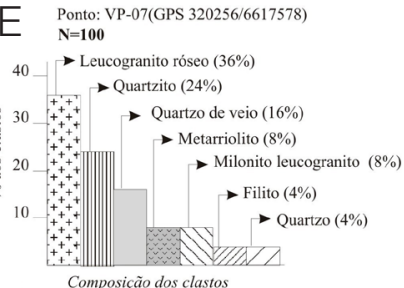

VP: Vale do Piquiri; N: número de medidas; fc: fator de consistência.

Figura 17. Seção colunar geral da Formação Rincão dos Mouras com as medidas dos vetores de dispersão de paleocorrentes e as análises de proveniência efetuadas. A, B e C: diagramas de proveniência do $3^{\circ}$ megaciclo, $\mathrm{D}$ e E: diagramas de proveniência do $1^{\circ}$ megaciclo. 
literatura sobre o tema (Mutti, 1992; Boiano, 1997; Mutti et al., 1999; Johnson et al., 2001).

Após o desenvolvimento dos sistemas de leques subaquosos e depósitos lacustres da Formação Passo da Capela, a provável reativação das falhas de borda da bacia propiciou o gigantesco aporte de sedimentos que supriu a Formação Rincão dos Mouras. A unidade, composta de arenitos e conglomerados aluviais, marca a inversão da Sub-bacia Camaquã Oriental, tanto no Vale do Piquiri/Rincão dos Mouras quanto no Arroio Boici (Fambrini, 1992; Sayeg et al., 1992; Sayeg, 1993; Fambrini et al., 1992; Fambrini, 2003; Fambrini e Fragoso-Cesar, 2006; Fambrini et al., 2011), com a instalação de altos que individualizaram a bacia e resultaram em uma configuração próxima da atual. A Formação Rincão dos Mouras reflete um evento de acomodação, aporte e preenchimento, interpretado como consequência direta do estabelecimento dos altos que limitaram a sub-bacia. Após a instalação dos corposlacustres da Formação Passo da Capela, decorrente da reativação das falhas a leste da sub-bacia, a presença de um alto e de uma escarpa abrupta no relevo geraram aumento tanto do volume de aporte sedimentar local quanto da granulometria desse sedimento, inibindo o escoamento dos detritos para regiões distais (bypassing). Assim, apesar de haver certo lapso de tempo entre a instalação da atividade tectônica e a atuação máxima dos processos de denudação dos altos, espessos depósitos - inicialmente de leques aluviais proximais e, finalmente, fluviais - instalaram-se sobre o pacote sedimentar da Formação Passo da Capela em um padrão regressivo de preenchimento da bacia.

A Formação Rincão dos Mouras possui uma evolução fortemente influenciada pela atividade tectônica nas falhas de borda, evidenciada por depósitos de leques aluviais proximais que transicionam para sistemas fluviais entrelaçados arenosos de alta energia em toda a sucessão (Figura 17). A interpretação de um ambiente de leques aluviais dominados por processos tipo enchentes em lençol implica em padrão de drenagem distributário (Blair e McPherson, 1994). A análise de paleocorrentes efetuada mostra consistência e baixa variância das medidas em cada estação, porém com uma grande variedade de direções entre as estações, revelando uma direção preferencial de fluxo em cada posição do sistema deposicional, adiante discutida.

Embora Oliveira e Fernandes $(1991,1992)$ tenham atribuído origem associada a falhas transcorrentes (strike-slip setting) para a Bacia do Camaquã, as análises de proveniência de clastos revelaram constantemente origens associadas às litologias do embasamento mais próximas dos depósitos, mesmo nos conglomerados mais inferiores. Tais evidências sugerem fortemente que a atividade tectônica responsável pela formação da bacia foi predominantemente de caráter normal, sem deslocamento lateral das áreas fonte em relação aos depósitos delas derivados, sendo as evidências estruturais de transcorrência provavelmente de deformações posteriores, ou mesmo anteriores do embasamento da bacia. Tal constatação fora observada por Fragoso-Cesar et al. (2001) e Fambrini et al. (2001) para falhas normais sin-deposicionais com evidências de sismitos.

As análises de proveniência efetuadas em todas as unidades propiciaram algumas conclusões:

1. indicam sempre fonte adjacente aos depósitos sedimentares;

2. indicam as fontes de detritos;

3. auxiliaram na diferenciação entre as formações Passo da Capela e Rincão dos Mouras.

A ocorrência nesta última de fragmentos de mármore e o aumento considerável da proporção de clastos do Granito Encruzilhada do Sul, situado a ENE da região do Vale do Piquiri/Rincão dos Mouras/Capané, foi mais um dos critérios utilizados na separação dessas unidades, sobretudo quando conglomerados estratificados de ambas se acham contíguos.

\section{CONCLUSÕES}

Os conglomerados dos leques subaquosos da Formação Passo da Capela apresentam composição dos clastos do arcabouço derivada de unidades da própria sub-bacia (arenitos, principalmente), indicando a atuação de processos de autofagia, bem como de rochas do embasamento (quartzitos, xistos, metarriolitos etc.). As análises de proveniência efetuadas mostraram-se coerentes com as de paleocorrentes. Elas indicam dispersão dos sedimentos a partir de SSW, onde se destacam litotipos oriundos do Complexo Porongos, tais como quartzitos, metarriolitos e milonitos em geral. A presença de clastos de granitos pode ser atribuída a núcleos graníticos preservados da intensa milonitização que afetou esse complexo de embasamento. Na região a leste de Capané, a análise de proveniência dos conglomerados indicou derivação principalmente do Sienito Piquiri, mas também de rochas do Granito Encruzilhada do Sul. É importante salientar que a proveniência reflete contribuição detrítica do embasamento adjacente ao depósito conglomerático (e.g. clastos do Sienito Piquiri), indicando, assim, que movimentações laterais do substrato da bacia não ocorreram ou, caso aconteceram, não foram importantes na deposição do Grupo Santa Bárbara. O estudo de proveniência indica, do mesmo modo, que o Sienito Piquiri seria embasamento das unidades sedimentares da bacia (Fambrini, em preparação) devido à:

1. presença de clastos de sienito no arcabouço dos conglomerados;

2. interdigitação entre as fácies conglomeráticas e de ritmitos; e

3. ausência de apófises do Sienito Piquiri nos sedimentos, como observado igualmente por Ketzer e Germany (1995). 
Os conglomerados aluviais da Formação Rincão dos Mouras possuem proveniência diversificada atestada pelas análises implementadas. Na base, ocorrem clastos de rochas metamórficas, correlacionadas ao Complexo Porongos (e.g. metarriolito), e da própria bacia (e.g. arenitos). A análise de proveniência sugere a denudação de altos de embasamento do Complexo Porongos e de turbiditos da Formação Passo da Capela. Na porção intermediária destacam-se clastos de granitos róseos e muscovita leucogranitos correlacionáveis ao Granito Encruzilhada do Sul, bem como clastos de litologias oriundas do Complexo Porongos. Fragmentos de sienito e traquito aparecem em pequena proporção, assim como arenitos e intraclastos argilosos. A análise de proveniência, aliada à de paleocorrentes efetuada, indicou que áreas a leste estavam sendo soerguidas e erodidas, como o Granito Encruzilhada do Sul e o próprio Complexo Porongos, e se comportaram como alto de embasamento fornecedor de sedimentos para a bacia. Para o topo voltam a predominar fragmentos do Complexo Porongos (e.g. mármores) e maior arredondamento dos clastos, compatível com o paleoambiente de rios entrelaçados que dominam essa porção. Isso decorre de uma mudança no embasamento da bacia, com o soerguimento de altos a NW, como se denota das paleocorrentes medidas que fluíram para SE. A análise de paleocorrentes implementada na Formação Rincão dos Mouras sugere controle tectônico importante durante o preenchimento da unidade, com mudanças de fontes de detritos para a bacia e soerguimento de altos então adjacentes. O soerguimento de altos internos propiciou a instalação de sistemas de leques aluviais e de planícies fluviais que caracterizam as sucessões basais dessa sequência. A integração dos dados obtidos aponta que o Grupo Santa Bárbara e, por extensão, todo o Supergrupo Camaquã, depositou-se em uma bacia extensional tipo rifte (Fragoso-Cesar et al., 2000), com falhas de borda de rejeito normal ou oblíquo, sem grandes rejeitos direcionais, cujo preenchimento sedimentar foi controlado, sobretudo, pelos seguintes fatores: subsidência mecânica, aporte sedimentar e padrões de transporte sedimentar. As análises de proveniência e de paleocorrentes indicam que os altos de Caçapava do Sul e da Serra das Encantadas serviram como área fonte para esses depósitos aluviais, sugerindo o soerguimento dos altos durante a evolução do preenchimento sedimentar dessa unidade (Fambrini et al., 1992, 2006; Fambrini e FragosoCesar, 2006; Fambrini et al., 2011, 2014).

Outras considerações podem ser feitas. Os depósitos expostos na Sub-bacia Camaquã Oriental apresentam evidências de rápido soterramento sob condições enérgicas em razão da relação entre sedimentos grossos e sedimentos finos. As análises de proveniência indicam multiplicidade de áreas fonte refletidas na variação composicional dos clastos contidos nos conglomerados, assim como retrabalhamento de unidades predecessoras configurando uma bacia "autofágica" (canibalismo) refletindo a geração de altos internos e a erosão de unidades gradativamente mais profundas, configurando uma estratigrafia invertida de área fonte (vulcânicas ácidas, xistos, quartzitos, granitos, calcários, granitos porfiríticos e milonitos). Isso indica uma taxa de soerguimento relativo muito intensa, pois se denuda espesso pacote de rochas do embasamento em apenas uma seção da bacia. As análises de proveniência indicam, ainda, proximidade da área fonte dos conglomerados da bacia. Essas evidências sugerem que a atividade tectônica responsável pela formação da bacia foi de caráter normal predominante, sem deslocamento lateral importante das áreas fonte em relação aos depósitos delas derivados (Fragoso-Cesar et al., 2001; Fambrini et al., 2001; Fambrini e Fragoso-Cesar, 2006). Como exemplo, temos o corpo plutônico do Sienito Piquiri, que teve a sua colocação antes da deposição de toda a sucessão sedimentar do Vale do Piquiri, constituindo um dos altos fornecedores de detritos para as fases iniciais do preenchimento da bacia (Fambrini e Fragoso-Cesar, 2006). Entende-se que a Sub-bacia Camaquã Oriental originou-se após a colocação do Sienito Piquiri (idade referida para o sienito de $611 \pm 3 \mathrm{Ma}$, segundo Philipp et al., 2002), considerado um "Clasto X" (sensu Aspler e Donaldson, 1985).

Outra conclusão fundamental decorrente desta pesquisa, somada à de outros trabalhos (e.g. Fragoso-Cesar et al., 2000, 2001; Fambrini, 2003; Almeida et al., 2010; Fambrini et al., 2014), envolveu a hipótese sobre a relação da Bacia do Camaquã com o embasamento adjacente: os depósitos do Supergrupo Camaquã foram gerados após a justaposição tectônica desses terrenos, seja em condições pós-orogênicas durante os estágios finais do Ciclo Brasiliano - preenchimento da Bacia do Camaquã —, ou, já em condições anorogênicas, durante os estágios iniciais de evolução da Bacia do Paraná, superposta (Fragoso-Cesar et al., 2003). Os dados estruturais e estratigráficos de fácies, proveniência e paleocorrentes, indicam que o Supergrupo Camaquã, sobretudo o Grupo Santa Bárbara, evoluíram em condições extensionais, o que implica na reformulação das hipóteses a respeito da tectônica geradora da Bacia do Camaquã.

\section{AGRADECIMENTOS}

Este trabalho é parte da Tese de Doutoramento de Gelson Luís Fambrini, que agradece a correta orientação e o companheirismo, amizade, paciência e atenção ao longo do Doutorado do Prof. Dr. Antonio Romalino Santos Fragoso Cesar (Universidade de São Paulo - USP). Os autores agradecem à Fundação de Amparo à Pesquisa do Estado de São Paulo (FAPESP) pelo suporte financeiro (Processos 98/04510-1 e 00/07510-4) e pela bolsa concedida a Gelson Luís Fambrini (98/03682-3) e Liliane Janikian. Claudio Riccomini e Renato Paes de Almeida agradecem ao Conselho Nacional de Deenvolvimento Científico e Tecnológico (CNPq) 
pelas bolsas de produtividade em pesquisa. Aos colegas Dra. Ana Paula Meireles Reis Pelosi (PETROBRAS) e Prof. Dr. Afonso César Rodrigues Nogueira (Universidade Federal do Pará - UFPA) pela colaboração nos trabalhos de campo e pelas discussões e sugestões apresentadas, bem como aos colegas geólogos Ana Paula Justo e Arthur Jarbas Cardoso da Silva (então estagiários de bolsas de iniciação científica do PIBIC) pelo auxílio nos trabalhos de campo. Dr. Marlei Antônio Carrari Chamani (USP) digitalizou o mapa geológico, a quem agradecemos. Os autores agradecem também à Companhia de Pesquisas e Recursos Minerais do Brasil (CPRM, Superintendência de Porto Alegre) pela disponibilização de fotografias aéreas, mapas e material utilizado no artigo. Agradecimentos são estendidos, ainda, ao Conselho Editorial da Geologia USP e aos revisores pela criteriosa, construtiva e exímia revisão e pelos valiosos comentários, sugestões e indagações que muito contribuíram para o aperfeiçoamento do manuscrito original.

\section{REFERÊNCIAS}

Almeida, F. F. M. (1969). Diferenciação tectônica da Plataforma Brasileira. XXIII Congresso Brasileiro de Geologia, v. 1, 29-46. Salvador: SBG.

Almeida, R. P. (2001). Evolução Tectono-sedimentar da Formação Santa Bárbara na Sub-Bacia Camaquã Ocidental. Dissertação (Mestrado). São Paulo: Instituto de Geociências - Universidade de São Paulo. 161p.

Almeida, R. P., Fragoso-Cesar, A. R. S., Janikian, L., Fambrini, G. L. (2012). Recurring extensional and strikeslip tectonics after the Neoproterozoic collisional events in the southern Mantiqueira province. Anais da Academia Brasileira de Ciências, 84, 347-376.

Almeida, R. P., Janikian, L., Fragoso-Cesar, A. R. S., Fambrini, G. L. (2010). The Ediacaran to Cambrian Rift System of Southeastern South America: Tectonic Implications. The Journal of Geology, 118, 145-161.

Almeida, R. P., Janikian, L., Fragoso-Cesar, A. R. S., Marconato, A. (2009). Evolution of a rift basin dominated by subaerial deposits: The Guaritas Rift, Early Cambrian, Southern Brazil. Sedimentary Geology, 217, 30-51.

Aspler, L. B., Donaldson, J. A. (1985). The Nonacho Basin (Early Proterozoic), Northwest Territories, Canada: Sedimentation and deformation in a strike-slip setting. In: K.T. Biddle \& N. Christie-Blick (Eds.), Strike-slipdeformation, basin formation and sedimentation (1-34). Tulsa: Society of Economic Paleontologists and Mineralogists.
Assine, M. L. (1994). Paleocorrentes e paleogeografia na Bacia do Araripe, nordeste do Brasil. Revista Brasileira de Geociências, 24(4), 223-232.

Bicca, M. M., Chemale Jr., F., Jelinek, A. R., Oliveira, C. H. E., Guadagnin, F., Armstrong, R. (2013). Tectonic evolution and provenance of the Santa Bárbara Group, Camaquã Mines region, Rio Grande do Sul, Brazil. Journal of South American Earth Sciences, 48, 173-192.

Blair, T. C. (1999a). Cause of dominance by sheetflood vs. debris-flow processes on two adjoining alluvial fans, Death Valley, California. Sedimentology, 46(6), 1015-1028.

Blair, T. C. (1999b). Sedimentary processes and facies of the waterlaid Anvil Spring Canyon alluvial fan, Death Valley, California. Sedimentology, 46(6), 913-940.

Blair, T. C., Bilodeau W. L. (1988). Development of tectonic cyclothems in rift, pull-apart, and foreland basins: Sedimentary response to episodic tectonism. Geology, 16, 517-520.

Blair, T. C., McPherson, J. G. (1994). Alluvial fans and their natural distinction from rivers based on morphology, hidraulic processes, sedimentary processes and facies assemblages. Journal of Sedimentary Petrology, Section A, 64(3), 450-489.

Blair, T. C., McPherson, J. G. (1999). Grain-size and textural classification of coarse sedimentary particles. Journal of Sedimentary Research, 69, 6-19.

Blair, T. C., McPherson, J. G. (2009). Alluvial fan process and forms. In: A.J. Parsons, A.D. Abrahams (Eds.), Geomorphology of Desert Environments (413-467). 2. ed. London: Springer Science+Business Media B.V.

Blissenbach, E. (1954). Geology of alluvial fans in semi-arid regions. Geological Society of America Bulletin, 65(2), 175-190.

Boiano, U. (1997). Anatomy of a siliciclastic turbidite basin: the Gorgoglione Flysch, Upper Miocene, southern Italy: physical stratigraphy, sedimentology and sequence-stratigraphic framework. Sedimentary Geology, 107(1), 231-262.

Bull, W. B. (1964). Alluvial fans and near-surface subsidence in Western Fresno County, California. U.S.G.S. Professional Paper 437A.70 p.

Bull, W. B. (1972). Recognition of alluvial-fan deposit in the stratigraphic record. In: J.K. Rigby e W.K. Hamblin (Eds.), Recognition of Ancient Sedimentary Environments (63-83). Tulsa: Society of Economic Paleontologists and Mineralogists. (Special Publication, 16). 
Cant, D. J., Walker, R. G. (1978). Fluvial process and facies sequences in the sandy braided South Saskatchewan River, Canada. Sedimentology, 25(5), 625-648.

Caravaca, G. (1998). Estratigrafia, faciologia e proveniência dos alogrupos Bom Jardim e Santa Bárbara na região de Encruzilhada do Sul, RS: uma contribuição à análise da Bacia do Camaquã. Dissertação (Mestrado). Porto Alegre: Instituto de Geociências - UFRGS. 274 p.

Caravaca, G., Fernandes, L. A. D., Menegat, R., Scherer, C. M. S. (1995). Proveniência dos conglomerados da Formação Arroio dos Nobres e implicações tectônicas na região de Encruzilhada do Sul, RS. V Simpósio Nacional de Estudos Tectônicos, 272-273. Gramado: SBG.

Coimbra, A. M., Fernandes, L. A., Moraes, M. C., Melo, M. S. (1992). Métodos de estudos de litologias e paleocorrentes de cascalhos em terraços do baixo Ribeira do Iguape (SP). Anais da Academia Brasileira de Ciências, 64(3), 253-267.

Collinson, J. D., Thompson, D. B. (1989). Sedimentary structures. London: Unwin Hyman. 207 p.

Corcoran, P. L., Mueller, W. U. (2002). The Effects of Weathering, Sorting and Source Composition in Archaean High-Relief Basins: Examples from the Slave Province, Northwest Territories, Canada. In: W. Altermann, P. L. Corcoran (Eds.),Precambrian Sedimentary Environments: A Modern Approach to Ancient Depositional Systems (183211). Londres: Blackwell Publishing. Davies I.C. \& Walker R.G. (1974). Transport and deposition of resedimented conglomerates: the Cap Enragé Formation, Gaspe, Quebec. Journal of Sedimentary Petrology, 44(4), 1200-1216.

Davies, I. C., Walker, R. G. (1974). Transport and deposition of resedimented conglomerates: the Cap Enragé Formation, Gaspe, Quebec. Journal of Sedimentary Petrology, 44(4), 1200-16.

Dickinson, W. R. (1988). Provenance and sediment dispersal in relation to paleotectonics and paleogeography of sedimentary basins. In: K.L. Kleinspehn, C. Paola (Eds.), New Perspectives in Basin Analysis (3-25).

Fambrini, G. L. (1992). Petrografia da cunha molássica brasiliana da região do Vale do Arroio Boici, RS. Relatório Final de Iniciação Científica. São Paulo.104 p. (inédito).

Fambrini, G. L. (1998). O Grupo Camaquã (Transição Proterozóico-Fanerozóico) na região das Minas do Camaquã, RS: análise estratigráfica de fácies, proveniência e paleocorrentes. Dissertação (Mestrado). São Paulo: Instituto de Geociências - USP. 182 p.
Fambrini, G. L. (2003). O Grupo Santa Bárbara (Neoproterozóico III) a norte do rio Camaquã, Rio Grande do Sul, Brasil. Tese (Doutorado). São Paulo: Instituto de Geociências - USP. 243 p.

Fambrini, G. L., Almeida, R. P., Fragoso-Cesar, A. R. S. (2006). Evolução estratigráfica do Grupo Santa Bárbara (Neoproterozóico III) na Sub-Bacia Camaquã Ocidental, Rio Grande do Sul, Brasil. Revista Brasileira de Geociências, 36(3), 550-565.

Fambrini, G. L., Fragoso-Cesar, A. R. S. (2006). Análise estratigráfica do Grupo Santa Bárbara (Ediacarano) na Sub-Bacia Camaquã Oriental, RS. Revista Brasileira de Geociências, 36(4), 663-678.

Fambrini, G. L., Fragoso-Cesar, A. R. S. (2006). Ensaio sobre a posição estratigráfica do Sienito Piquiri em relação à Bacia do Camaquã, RS. In: XLIII Congresso Brasileiro de Geologia, p. 101. Aracajú: SBG.

Fambrini, G. L., Fragoso-Cesar, A. R. S., Pelosi, A. P. M. R., Janikian, L., Almeida, R. P. (2011). Análise de proveniência de conglomerados e arenitos do Grupo Santa Bárbara (Ediacarano) na Sub-Bacia Camaquã Oriental, RS: implicações tectônicas. XIII Simpósio Nacional de Estudos Tectônicos / VII International Symposium on Tectonics, v. único, 448-421. Campinas: SBG. CD-ROM.

Fambrini, G. L., Fragoso-Cesar, A. R. S., Riccomini, C., Janikian, L., Almeida, R. P., Pelosi, A. P. M. R. (2001). Tectônica extensional sin-deposicional na Formação Santa Bárbara, Bacia do Camaquã, RS (Neoproterozóico IIICambriano Inferior). VIII Simpósio Nacional de Estudos Tectônicos, v. único, 149-150. Recife: SBG/ABGP.

Fambrini, G. L., Fragoso-Cesar, A. R. S., Silva-Filho, W. F., Teixeira, G., Sayeg, H. S., Machado, R. (1998). Análise estratigráfica de fácies, proveniência e paleocorrentes do Grupo Camaquã (transição Proterozóico-Cambriano) na Mina Uruguai e suas implicações na evolução tectonosedimentar da Bacia do Camaquã, RS. Boletim IG-USP, Série Cientifica, 29, 39-69.

Fambrini, G. L., Janikian, L., Almeida, R. P., Fragoso-Cesar, A. R. S. (2003). O Grupo Santa Bárbara (Neoproterozóico III) na Sub-Bacia Camaquã Central, RS. I Encontro sobre a Estratigrafia do Rio Grande do Sul: Escudo e Bacias, v. 1, 116-122. Porto Alegre: SBG/UFRGS.

Fambrini, G. L., Janikian, L., Almeida, R. P., Fragoso-Cesar, A. R. S. (2005). O Grupo Santa Bárbara (Ediacarano) na Sub-Bacia Camaquã Central, RS: estratigrafia e sistemas deposicionais. Revista Brasileira de Geociências, 35(2), 227-238. 
Fambrini, G. L., Janikian, L., Almeida, R. P., Fragoso-Cesar, A. R. S. (2007). Evolução estratigráfica e paleogeográfica do Grupo Santa Bárbara (Ediacarano) na Sub-bacia Camaquã Central, RS. Geologia USP. Série Cientifica, 7(2), 1-24.

Fambrini, G. L., Janikian, L., Almeida, R. P., Fragoso-Cesar, A. R. S. (2014). Evolução tectônica e estratigráfica do Grupo Santa Bárbara (Ediacarano) na Sub-Bacia Camaquã Central, RS, sul do Brasil: registro de sedimentação continental na assembléia do Gondwana. Comunicações Geológicas, 101, 39-54.

Fambrini, G. L., Saes, G. S., Fragoso-Cesar, A. R. S., SilvaFilho, W. F., Sayeg, H. S., Teixeira, G., Machado, R., McReath, I., Ribeiro de Almeida, T. I., Phillip, R. P. (1996). Sistemas costeiros da Formação Santa Bárbara, Bacia do Camaquã, RS (transição Proterozóico-Fanerozóico): registro preliminar da sedimentação em ambiente de águas rasas dominado por ondas. XXXIX Congresso Brasileiro de Geologia, v. 2, 204-206. Salvador: SBG.

Fambrini, G. L., Sayeg, H. S., Fragoso-Cesar, A. R. S. (1992). Variação de áreas-fonte da Formação Arroio dos Nobres (Cambriano) no Vale do Arroio Boici, RS: análise estratigráfica de proveniência e de paleocorrentes. XXXVII Congresso Brasileiro de Geologia, v. 2, p. 441. São Paulo: SBG.

Folk R.L. (1968). Petrology of Sedimentary Rocks. The University of Texas, Austin, Hemphill's. 170 p.

Fragoso-Cesar, A. R. S. (1984). Evolução paleoambiental e tectônica da Bacia do Camaquã: uma introdução. Dissertação (Mestrado). Porto Alegre: Instituto de Geociências - UFRGS. 103 p.

Fragoso-Cesar, A. R. S. (1991). Tectônica de Placas no Ciclo Brasiliano: as orogenias dos Cinturões Dom Feliciano e Ribeira no Rio Grande do Sul. Tese (Doutorado). São Paulo: Instituto de Geociências - USP. 243 p.

Fragoso-Cesar, A. R. S. (2008). Novas considerações sobre o Ciclo Brasiliano. XLIV Congresso Brasileiro de Geologia, 28. Curitiba: SBG.

Fragoso-Cesar, A. R. S., Almeida, R. P., Fambrini, G. L., Pelosi, A. P. M. R., Janikian, L. (2003). A Bacia Camaquã: um sistema intracontinental anorogênico de rifts do Neoproterozóico III-Eopaleozóico no Rio Grande do Sul. I Encontro sobre a Estratigrafia do Rio Grande do Sul: Escudo e Bacias, v. 1, 139-144. Porto Alegre: SBG.

Fragoso-Cesar, A. R. S., Almeida, R. P., Pelosi, A. P. M. R., Janikian, L., Fambrini, G. L. (2002). Grupo
Camaquã (Neoproterozóico III-Eopaleozóico): a cobertura anorogênica do Escudo Gaúcho no Rio Grande do Sul. VLI Congresso Brasileiro de Geologia, 307. João Pessoa: SBG.

Fragoso-Cesar, A. R. S., Faccini, U. F., Paim, P. S. G., Lavina, E. L., Altamirano, J. A. F. (1985). Revisão na estratigrafia das molassas do Ciclo Brasiliano no Rio Grande do Sul. II Simpósio Sul-Brasileiro de Geologia, v. 1, 477-491. Florianópolis: SBG.

Fragoso-Cesar, A. R. S., Fambrini, G. L., Almeida, R. P., Pelosi, A. P. M. R., Janikian, L., Riccomini, C., Machado, R., Nogueira, A. C. R., Saes, G. S. (2000). The Camaquã extensional basin: Neoproterozoic to early Cambrian sequences in southernmost Brazil. Revista Brasileira de Geociências, 30(3), 438-441.

Fragoso-Cesar, A. R. S., Fambrini, G. L., Riccomini, C., Janikian, L., Almeida, R. P., Pelosi, A. P. M. R., Machado, R. (2001). Estruturas induzidas por abalos sísmicos na Seqüência Santa Bárbara (Neoproterozóico III-Eocambriano), Bacia do Camaquã, RS: o exemplo do Passo da Capela. Revista Brasileira de Geociências, 31(2), 155-162.

Fragoso-Cesar, A. R. S., Lavina, E. L., Paim, P. S. G., Faccini, U. F. (1984). A Antefossa Molássica do Cinturão Dom Feliciano no Escudo do Rio Grande do Sul. XXXIII Congresso Brasileiro de Geologia, v. 7, 3272-3283. Rio de Janeiro: SBG.

Fragoso-Cesar, A. R. S., Wernick, E., Soliani Jr., E. (1982). Evolução geotectônica do Cinturão Dom Feliciano - uma contribuição através da aplicação do modelo da Tectônica de Placas. XXXII Congresso Brasileiro de Geologia, v. 1, 13-23. Salvador: SBG.

Ghibaudo, G. (1992). Subaqueous sediment gravity flow deposits: practical criteria for their field description and classification. Sedimentology, 39(3), 423-454.

Gloppen, T. G., Steel, R. J. (1981). The deposits, internal structure and geometry in six alluvial fan-fan delta bodies (Devonian-Norway) - a study in the significance of bedding sequence in conglomerates. In: F. G. Ethridge, R. M. Flores (Eds.), Recent and Ancient Depositional Environments: models for exploration (49-69). Tulsa: Society of Economic Paleontologists and Mineralogists. (Special Publication, 39).

Graham, J. (1988). Collection and analysis of field data. In: M. Tucker (Ed.), Techniques in sedimentology (5-62). Londres: Blackwell Scientific Publications. 
Gresse, P. G., Chemale Jr., F., Silva, L. C., Walraven, F., Hartmann, L. A. (1996). Late- to post-orogenic basins of the Pan-African-Brasiliano collision orogen in southern Africa and southern Brazil. Basin Research, 8(2), 157-171.

Hooke, R. L. (1967). Processes in arid-region alluvial fans. Journal of Geology, 75, 438-460.

Ibbeken, H., Schleyer, R. (1991). Source and Sediment A case study of provenance and mass balance at an active plate margin (Calabria, southern Italy). Berlin Heidelberg: Springer-Verlag. 286 p.

James, N. P., Dalrymple, R. W. (2010). Facies models 4. Canada: Geological Association of Canada. (Geotext 6). 586 p.

Janikian, L., Almeida, R. P., Fragoso-Cesar, A. R. S., Fambrini, G. L. (2003). Redefinição do Grupo Bom Jardim (Neoproterozóico III) em sua área-tipo: litoestratigrafia, evolução paleoambiental e contexto tectônico. Revista Brasileira de Geociências, 33(4), 349-362.

Janikian, L., Almeida, R. P., Fragoso-Cesar, A. R. S., Martins, V. T. D. S., Dantas, E. L., Tohver, E., McReath, I., D’AgrellaFilho, M. S. (2012). Ages (U-Pb SHRIMP and LAICPMS) and stratigraphic evolution of the Neoproterozoic volcanosedimentary successions from the extensional Camaquã Basin, Southern Brazil. Gondwana Research, 21, 466-482.

Johnson, S. D., Flint, S., Hinds, D., Ville Wickens, H. (2001). Anatomy, geometry and sequence stratigraphy of basin floor to slope turbidite systems, Tanqua Karoo, South Africa. Sedimentology, 48(5), 987-1023.

Ketzer, J. M., Germany, J. G. (1995). Discussão do posicionamento estratigráfico das unidades eo-paleozóicas da região de Encruzilhada do Sul, RS. VI Simpósio Sul-Brasileiro de Geologia / I Encontro de Geologia do Cone Sul, p. 192-193. Porto Alegre: SBG.

Lavina, E. L., Faccini, U. F., Paim, P. S. G., Fragoso-Cesar, A. R. S. (1985). Ambientes de sedimentação da Bacia do Camaquã, Eo-Paleozóico do Rio Grande do Sul. Acta Geologica Leopoldensia, 9(21), 185-227.

Lima, E. F., Nardi, L. S. V. (1998). The Lavras do Sul Shoshonitic Association: implications for the origin and evolution of Neoproterozoic shoshonitic magmatism in southernmost Brazil. Journal of South American Earth Sciences, 11(1), 67-77.

Lowe, D. R. (1979). Sediment gravity flows: their classification and some problems of application to natural flows and their deposits. In: L. A. Doyle, O. H. Pilkey Jr. (Eds.), Geology of continental slopes (75-82). Society of Economic Paleontologists and Mineralogists. (Special Publication, 27).

Lowe, D. R. (1982). Sediment gravity flows: II. Depositional models with special reference to the deposits of high-density turbidity currents. Journal of Sedimentary Petrology, 52(1), 279-297.

Machado, R., Sayeg, H. S. (1992). Aplicação da análise geométrica e cinemática nos falhamentos que condicionaram a bacia molássica do Arroio Boici, RS. I Workshop sobre as bacias molássicas brasilianas, p. 73-76. São Leopoldo: SBG/UNISINOS.

Marconato, A., Almeida, R. P., Turra, B. B.; Fragoso-Cesar, A. R. S. (2014). Pre-vegetation fluvial floodplains and channelbelts in the Late Neoproterozoic-Cambrian Santa Bárbara group (Southern Brazil). Sedimentary Geology, 300, 49-61.

McLaurin, B. T., Steel, R. J. (2007). Architecture and origin of an amalgamated fluvial sheet sand, lower Castlegate Formation, Book Cliffs, Utah. Sedimentary Geology, 197, 291-311.

Miall, A. D. (1977). A review of the braided-rivers depositional environment. Earth Science Review, 13(1), 1-62.

Miall, A. D. (1978). Lithofacies types and vertical profile models in braided-rivers deposits: a summary. In: A. D. Miall (Ed.), Fluvial Sedimentology (5, 597-604). Calgary: Canadian Society of Petroleum Geologists Memoir.

Miall, A. D. (1981). Analysis of fluvial depositional systems: AAPG Educational Course Note Series, p. 1-75. American Association of Petroleum Geologists. (Special Publication, 20).

Miall, A. D. (1988). Architectural elements and bounding surfaces in fluvial deposits: anatomy of the Kayenta Formation (Lower Jurassic), Southwest Colorado. Sedimentary Geology, 55, 233-262.

Miall, A. D. (1992). Alluvial deposits. In: R. G. Walker, N. P. James (Eds.), Facies models: response to sea level change (119-142). Waterloo, Ontario: Geological Association of Canada.

Miall, A. D. (1996). The geology of fluvial deposits: sedimentary facies, basin analysis and petroleum geology. Heidelberg: Springer-Verlag Berlin. 582 p.

Miall, A. D. (2000). Principles of sedimentary basin analysis. 3. ed. New York: Springer-Verlag. 616 p. 
Miall, A. D. (2014). Fluvial Depositional Systems. Berlin: Springer (Geology). $316 \mathrm{p}$.

Miall, A. D., Jones B. G. (2003). Fluvial architecture of the Hawkesbury Sandstone (Triassic), near Sydney, Australia. Journal of Sedimentary Research, 73(4), 531-545.

Middleton, G. V., Hampton, M. A. (1976). Subaqueous sediment transport and deposition by sediment gravity flows. In: D. J. Stanley, D. J. P. Swift (Eds.), Marine sediment transport and environment management (197-218). Nova York: John Wiley and Sons.

Mills, P.C. (1983). Genesis and diagnostic value of softsediment deformation structures - a review. Sedimentary Geology, 35(2), 83-104.

Mulder, T., Alexander, J. (2001). The physical character of sedimentary density currents and their deposits. Sedimentology, 48, 269-299.

Mutti, E. (1992). Turbidite Sandstones. Milan: AGIP Special Publication. 275 p.

Mutti, E., Tinterri, R., Remacha, E., Mavilla, N., Angella, S., Fava, L. (1999). An introduction to the analysis of ancient turbidite basins from an outcrop perspective. Tulsa: American Association of Petroleum Geologists. (Continuing Education Course Note Series, 39). 61 p.

Nilsen, T. H. (1969). Old red sedimentation in the BuelandetVaerlandet Devonian District, western Norway. Sedimentary Geology, 3, 35-57.

Nilsen, T. H. (1982). Alluvial fans. In: P. A. Scholle, D. Spearing (Eds.), Sandstone Depositional Environments (2-84). Tulsa: American Association of Petroleum Geologists. (Memoir 31).

Nilsen, T. H. (1985). Modern and ancient alluvial fan deposits. New York: Van Nostrand Reinhold. 372 p.

Oliveira, J. M. M. T., Fernandes, L. A. D. (1991). Estágios finais da evolução do Cinturão Dom Feliciano: Tectônica e sedimentação da Formação Arroio dos Nobres. III Simpósio Nacional de Estudos Tectônicos, p. 58-59. Rio Claro: SBG.

Oliveira, J. M. M. T., Fernandes, L. A. D. (1992). Bacias molássicas brasilianas, mito ou realidade? I Workshop sobre as Bacias Molássicas Brasilianas, p. 97-105. São Leopoldo: SBG/UNISINOS.
Paim, P. S. G. (1994). Depositional Systems and Paleogeographical Evolution of the Camaquã and Santa Bárbara Basins, Brazil. Tese (Doutorado). Oxford. 277 p.

Paim, P. S. G. (1995). Fluvial paleogeography of Guaritas depositional sequence of southern Brazil. In: A. G. Plint (Ed.), Sedimentary Facies Analysis (3-16). International Association of Sedimentologists. (Special Publication, 22).

Paim, P. S. G., Chemale Jr., F., Lopes, R. C. (2002). A Bacia do Camaquã. In: M. Holtz, L. F. De Ros (Eds.), Geologia do Rio Grande do Sul, 231-274. Rio Grande do Sul: Edição CIGO/UFRGS.

Paim, P. S. G., Faccini, U. F., Fragoso-Cesar, A. R. S., Lavina, E. L. (1986). Modelo submarino para a Formação Maricá no Vale do Piquiri (RS): Leques Submarinos X "Debris Apron". XXXIV Congresso Brasileiro de Geologia, p. 357-367. Goiânia: SBG.

Paim, P. S. G., Faccini, U. F., Netto, R.G., Nowatzki, C.H. (1992). Estratigrafia de seqüências e sistemas deposicionais das bacias do Camaquã e Santa Bárbara, Eopaleozóico do RS (Brasil). Correlación Geologica, 9, 41-45.

Philipp, R. P., Machado, R., Nardi, L. V. S., Lafon, J. M. (2002). O magmatismo granítico neoproterozóico do Batólito Pelotas no sul do Brasil: novos dados e revisão da geocronologia regional. Revista Brasileira de Geociências, 32(2), 277-290.

Potter, P. E., Pettijohn, F. J. (1977). Paleocurrents and basin analysis. 2. ed. New York: Springer-Verlag. 425 p.

Reading, H. G. (1996). Sedimentary environments: processes, facies and stratigraphy. Londres: Blackwell Sci. 668 p.

Ribeiro, M., Bocchi, P. R., Figueiredo Filho, P. M., Tessari, R. I. (1966). Geologia da Quadrícula de Caçapava do Sul, Rio Grande do Sul. Rio de Janeiro: DNPM/DFPM. 232 p. (Boletim 127).

Robertson, J. F. (1966). Revision on stratigraphy and nomenclature of rock units in Caçapava-Lavras Region. Notas e Estudos, 1(2), 41-54.

Rust, B. R. (1972). Structure and process in a braided river. Sedimentology, 18(3-4), 221-245.

Sayeg, H. S. (1993). Evolução geológica brasiliana da Bacia do Arroio Boici, RS. Dissertação (Mestrado). São Paulo: Instituto de Geociências - USP. 
Sayeg, H. S., Fambrini, G. L., Machado, R., Fragoso-Cesar, A. R. S. (1992). Evolução brasiliana da bacia transcorrente do Arroio Boici, RS. I Workshop sobre as bacias molássicas brasilianas, p. 129-132. São Leopoldo: SBG/UNISINOS.

Schanley, K. W., McCabe, P. J. (1994). Perspectives on the sequence stratigraphy of continental strata. American Association of Petroleum Geologists Bull, 78, 544-568.

Schultz, A. W. (1984). Subaerial debris-flow deposition in the Upper Paleozoic Cutler Formation, western Colorado. Journal of Sedimentary Petrology, 54(3), 759-772.

Seilacher, A. (1969). Fault-graded beds interpreted as seismites. Sedimentology, 13, 155-159.

Selley, R. C. (1987). Ancient sedimentary environments. London: Chapman Hall. 317 p.

Selley, R. C. (2000). Applied sedimentology environments, a brief survey. London: Academic Press.

Sommer, C.A., Lima, E.F., Nardi, L.V.S., Liz, J.D., Waichel, B.L. (2006). The evolution of Neoproterozoic magmatism in Southernmost Brazil: shoshonitic, high-K tholeiitic and silicasaturated, sodic alkaline volcanism in post-collisional basins. Anais da Academia Brasileira de Ciências, 78, 573-589.

Steel, R. J., Maehle, S., Nilsen, H., RÆe, S. L., Spinnangar, A. (1977). Coarsening-upward cycles in the alluvium of Hornelen Basin (Devonian), Norway: sedimentation response to tectonic events. Geological Society of America Bulletin, 88, 1124-1134.

Terry, J. P., Goff, J. (2014). Megaclasts: proposed revised nomenclature at the coarse end of the Udden-Wentworth grainsize scale for sedimentary particles. Journal of Sedimentary Research, 84, 192-197.
Tessari, R I., Giffoni, L. E. (1970). Geologia da região de Piratini, Pinheiro Machado e Bagé, Rio Grande do Sul. Rio de Janeiro: DNPM, 246.122 p.(Boletim da Divisão de Geologia e Mineralogia, 246).

Tessari, R. I., Picada, R. S. (1966). Geologia da Quadrícula Encruzilhada do Sul, Rio Grande do Sul, Brasil. Rio de Janeiro: DNPM/DFPM. 147 p. (Boletim da Divisão de Geologia e Mineralogia, 124).

Tucker, M. E. (1989). The field description of sedimentary rocks (91-97). Londres: Geological Society of London. (Handbook Series).

Vail, P. R., Mitchum, R. M. Jr., Todd, R. G., Widmier, J. M., Thompson, S. III., Sangree, J. B., Bubb, J. N., Hatlelid, W. G. (1977). Seismic stratigraphy and global changes of sea-level. In: C. E. Payton (Ed.), Seismic stratigraphy - applications to hidrocarbon exploration (26, 63-97). American Association of Petroleum Geologists Memoir.

Vittori, E., Labini, S. S., Serva, L. (1991). Palaeoseismology: review of the state-of-the-art. Tectonophysics, 193(1-3), 9-32.

Walker, R. G. (1992). Facies, facies models and modern stratigraphic concepts. In: R. G. Walker, N. P. James (Eds.), Facies models: Response to sea level change (1-14). Waterloo, Ontario: Geological Association of Canada.

Walker, R. G., James, N. P. (1992). Facies models: Response to sea level changes. Canada: Geological Association of Canada. 212 p.

Widner, W., Lima, E. F., Nardi, L. V. S., Sommer, C. A. (2002). Volcanic cycles and setting in the Neoproterozoic III to Ordovician Camaquã Basin succession in southern Brazil: characteristics of post-collisional magmatism. Journal of Volcanology and Geothermal Research, 118, 261-283. 